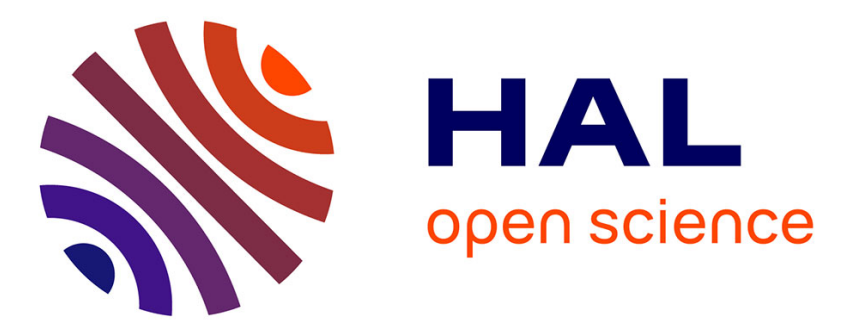

\title{
Mapping public support for innovation: a comparison of policy alignment in the UK and France
}

Isabel Maria Freitas Bodas, Nick von Tunzelmann

\section{To cite this version:}

Isabel Maria Freitas Bodas, Nick von Tunzelmann. Mapping public support for innovation: a comparison of policy alignment in the UK and France. Research Policy, 2008, 37 (9), pp.1446-1464. 10.1016/j.respol.2008.05.005 . hal-01487464

\section{HAL Id: hal-01487464 \\ http://hal.grenoble-em.com/hal-01487464}

Submitted on 12 Mar 2017

HAL is a multi-disciplinary open access archive for the deposit and dissemination of scientific research documents, whether they are published or not. The documents may come from teaching and research institutions in France or abroad, or from public or private research centers.
L'archive ouverte pluridisciplinaire HAL, est destinée au dépôt et à la diffusion de documents scientifiques de niveau recherche, publiés ou non, émanant des établissements d'enseignement et de recherche français ou étrangers, des laboratoires publics ou privés. 
Cite as: “Bodas Freitas, I.M. and von Tunzelmann, N. (2008). Mapping Public support for innovation in a three-dimensional space. Research Policy, 37(9), 1446-1464."

\title{
MAPPING PUBLIC SUPPORT FOR INNOVATION: A COMPARISON OF POLICY ALIGNMENT IN THE UK AND FRANCE
}

\author{
Isabel Maria Bodas Freitas
}

and

Nick von Tunzelmann

\begin{abstract}
$^{1}$
This paper proposes and tests a three-dimensional model of public support design as a framework to compare public incentives for innovation in firms through time and across countries, and consequently to compare forms of policy alignment of innovation objectives in an economy. Using data on 149 French and British policy programmes from the early 1980s to 2002 , this paper shows that policy-makers implement programmes within a different threedimensional design space in order to align several distinctive objectives and consequently strengthen the impact of governmental measures. Moreover, as the objectives of the national players and policy-makers evolved, the portfolio of innovation policies also evolved in their separate ways. Nevertheless, some similar trends are also observed.
\end{abstract}

Keywords: Innovation policy, Innovation networks, Policy alignment, Policy design

JEL - code(s). O33, O38, O57

\footnotetext{
${ }^{1}$ Acknowledgment: The authors would like to thank C. Bessede (SQUALPI, MINEFI), R. Downing (SBS, DTI), D. Lalanne (DARPMI, MINEFI), P. Lanbadieu (DRIRE Alsace), J-L Langeron (SQUALPI, MINEFI) and J. Launchbury (SBS, DTI) for their availability and the important discussion on the content of the database on policy programmes used in this paper. The authors acknowledge also the comments and suggestions of two anonymous referees. The usual disclaimers apply.
} 


\section{Introduction}

The benchmarking and comparison of national policies is increasingly a priority of the European Commission, which aims at identifying best-practices in the design of policies to provide recommendations to national governments. However, a variety of activities with different designs may need to be undertaken within a country to address and align the diverse objectives of the many different actors (Callon et al., 1991; Najmabadi and Lall, 1995; Goldman et al., 1997). Consequently, key policy dimensions need to be identified in order to benchmark specific policy incentives across different national environments.

Some studies have focused on identifying typologies of policy design, but not on empirically analysing the relevance of their proposed design dimensions for differentiating policy programmes. In this manner, Cantner and Pyka (2001) analyse the evolution of the technology policy of Germany over two decades based on two predetermined axes - efforts in basic/applied research and precise/open research targets. Their empirical methodology consisted of classifying each technology area into one of the four predetermined types of policies and then to analyse the evolution of their funding. In their study, programmes in one technological area were thus expected to maintain their characteristics over more than 20 years. Moreover, despite the efforts of Foray and Llerena (1996), empirical deductive identification of the main design dimensions to assess and compare international patterns of public efforts in aligning national innovation objectives has still not been achieved. Thus, in the literature, the empirical deduction and test of the main design axes of innovation policies has been much neglected, owing to lack of detailed data on the design of policy programmes over a large period of time for more than one particular economy.

Hence, this paper proposes and tests a three-dimensional model of public support design vertical/horizontal knowledge objectives, specific/general support provided, and local/central implementation - as a framework to characterise and compare national policy incentives for innovation, modernisation and management in firms over time and across countries. Additionally, this paper assesses whether there exists a predominant national portfolio of policy activities with a specific organisational design, to enhance the coordination of objectives of demand for and supply of innovative inputs and how these might evolve. This is a key issue for the 'alignment' of government policies with national targets. For this purpose, we rely on a dataset of 149 French and British policy programmes, aimed at supporting management improvement and innovation in firms, launched from the early 1980s to 2002.

This paper shows that the alignment of national innovation objectives and activities in an economy seems to require the implementation of several policy activities, with different three- 
dimensional design space. Over time, as the players in the innovation system and their specific objectives evolve, the portfolio of policy design also evolves. The national pattern of alignment of objectives of national players towards innovation, as undertaken by policy-makers, depends on the present and past specificities and characteristics of the national innovation systems and of the innovation support networks. Nevertheless, in both countries, the role of policy-making became increasingly recognised as a provider of market incentives to new and/or better business-to-business services markets.

The paper is organised as follows. Section 2 reviews the importance of the alignment of distinctive objectives of multiple diverse players towards innovation development and diffusion. Section 3 reviews the existing contributions to mapping innovation policies and their design. In Section 4, a framework is proposed to compare policy design as well as the alignment strategies of policy-makers. Methodology and data used to undertake the statistical and historical analysis are presented in Section 5. Section 6 gives the empirical results on the axes of policy design. Section 7 presents and discusses the empirical results on the evolution of the patterns of alignment of innovation policies in France and the UK. Section 8 summarises the main findings and implications of this study.

\section{The importance of alignment of activities and objectives for innovation policy- makers}

The competitiveness of firms reflects their quick and appropriate response to external challenges through the adoption of innovations and the development of new capabilities. Therefore, policy recommendations tend to refer to measures that support the dissemination of innovations.

On the one hand, emphasis can lie on the information needs of firms to adopt innovations. Here, policy-makers are often recommended to provide financial support for such purposes (such as training, research and modernisation), to invest in knowledge codification, to support the creation of organisations responsible for identifying best-practices, and to make that bestpractice information available to other actors and firms (David and Foray, 1996; Cowan and Foray, 1997). On the other hand, by emphasising that firms need more than simply being made aware of the new technology to decide to adopt, some authors suggest that policy-makers invest in the development of an appropriate supply structure of innovative inputs, such as particular technological consultancy, advice or information (Wegloop, 1995; Teubal, 1997; Metcalfe, 2001; Metcalfe and Georghiou, 2005). Thus, to support national competitiveness, governments are called on to support the development of a technology through a critical initial mass of innovation users, as well as to encourage the development of a fruitful innovation supply 
structure to support innovation diffusion among late-adopters (Justman and Teubal, 1996; Lipsey and Carlaw, 1997; Teubal and Andersen, 2000).

Indeed, only through coordinated public investment in the development and diffusion of technologies, skills, information, and innovative supporting services might policy-makers expect to enhance the alignment of objectives and of knowledge flows of several distinctive actors - firms with diverse capabilities, business services providers, technical and professional organisations - towards innovation; and consequently speed adoption of innovations and the renewal of firm capabilities (Callon et al., 1991b; Najmabadi and Lall, 1995; Goldman et al., 1997). In particular, the coordination of activities and objectives of demand for and supply of different innovative inputs over time seems crucial for accelerating the speed and the level of innovation adoption and restructuring of capabilities of national firms (Justman and Teubal, 1996; Teubal and Andersen, 2000). Still, the importance of direct public support for alignment of activities and objectives of demand and supply through time might be reduced when new market activities emerge to supply firms with access to inputs for innovation adoption and for the development of new capabilities (Teubal and Andersen, 2000).

However, different technological and institutional environments may respond diversely to similar incentives. Consequently, replication of policies tends to be ineffective (Callon et al., 1991; Kooiman, 1993; Najmabadi and Lall, 1995; Goldman et al., 1997). Yet, policy-makers can play a major role in supporting the diffusion of innovations and renewal of capabilities among national firms if they manage to address, coordinate and align the distinctive objectives of multiple diverse players towards innovation development and diffusion. Hence, policymakers may need to define the main national objectives and implement several policy programmes that address the diversity of national players with different objectives, in order to strengthen the impact of governmental measures. In other words, to leverage national alignment of objectives and knowledge flows of several distinctive actors, certain combinations of a variety of policy programmes with specific organisational design may be required.

By providing a design space of public support for the diffusion of management best-practices, the three-dimensional framework developed in this paper is intended to facilitate the characterisation and measurement of national incentives, as well as the comparison of national alignment strategies undertaken by innovation policy-makers. Moreover, it permits a better understanding of why and how the design of policy programmes needs to change to adjust for different objectives, periods of time or political contexts. 


\section{Mapping innovation policies and their design}

The categorisation of policy-making as a concern of innovation studies has been surprisingly limited, despite the focus on policy issues in this field. The forms taken by governance - which can briefly be defined as "organizing collective action" - are known to co-evolve in relation to major changes in technological systems, but the understanding of how this occurs is still very weak (von Tunzelmann, 2003). It is also observed that the forms of governance systems are complex in structure and involve a range of actors (firms, non-profit organisations, governments, households, etc.) in at least three modes (markets, hierarchies and networks) (ibid.).

In a world of competing and complex national systems of innovation policy-making, it has come to be recognised that success tends to involve a suitable 'alignment' between policy design and policy objectives (e.g. McGowan et al., 2004). This has been argued for many years in the domain of macroeconomic policy, where a simple correspondence between the number of targets and the number of instruments in play to attain those targets - while a first step to successful policy-making - may not be sufficient (Musgrave, 1959). In innovation systems, the issue is still more problematic because of its inherent complexity. Innovation policy has to encompass systems that differ functionally (technology, production, finance, marketing, management), in resources (various types of labour, capital and natural resources), and spatially (local, regional. national and supranational levels) (McGowan et al., 2004: ch. 3). 'Design' represents the ways in which these multiple layers of systems are individually and collectively structured and controlled to yield benefits, and in this respect policy systems are no different from other facets to which they apply. In other words, good policy design is, in part, the expression of a satisfactory alignment process.

For the last 20 years, policy researchers have been looking for general and very common characteristics of policies that would allow comparisons across states and countries (Schneider and Ingram, 1988; Blair, 2002). Some frameworks have been put forward and used for analysing and evaluating programmes and policies ${ }^{2}$ based in three to five policy aspects. In particular, Schneider and Ingram (1988) propose that the design of a policy can be largely defined by its goals and targets, its agents (i.e. in policy implementation and management), and its linkages (i.e. policy tools or instruments). Similarly, (Peters, 2000: 37) argues that "the

\footnotetext{
${ }^{2}$ It is helpful to draw a distinction between policies and programmes, since a specific innovation policy is likely to lead to the implementation of several programmes with different design characteristics to achieve its goals.
} 
(policy) analyst needs to think about 3-way matching: the instrument, the policy problem and the managerial technique".

Moreover, out of their concern with evaluating technological development programmes, innovation researchers have developed evaluation frameworks focusing on similar dimensions to those proposed by the policy analysts. For instance, Callon et al. (1991a) propose three aspects that need to be addressed by evaluators of technological programmes, the quality of the outputs, the effects, and the management efficiency. These analytical dimensions aim roughly at measuring the impact of the incentives, of the design to achieve the targets, and of the implementation infrastructures on the innovation networks, i.e. the impact of technological programmes on science, technology and market-place and their links (Callon et al., 1991a). Similarly, the BETA evaluation methodology for large technological programmes, which proposes to focus on effects that are classified as technological (type of objectives and outcomes expected and achieved), organisational (form in which the project is executed and managed) and work (impact of the incentives put forward by the programme), aims mainly at capturing comparable aspects (Furtado et al., 1999).

Therefore, despite not providing a clear and fully-developed methodological framework, the literature suggests that the design of policy programmes is most often defined variously by the objectives or the type of knowledge that is addressed, the way implementation is organised, and the policy tools or the type of support/incentive provided. In particular, these three dimensions have been analysed and used individually or in combination, by both innovation and policy researchers. In particular, public policy researchers have made efforts to explore bridges between delivery and implementation mechanisms, and policy tools (Sabatier, 1986; Peters, 2000; Blair, 2002).

Among innovation researchers, Ergas (1987) proposed a division into mission-oriented versus diffusion-oriented policies, according to their knowledge objectives (i.e. supporting knowledge creation vs. the diffusion of existing knowledge). In Ergas's account, both France and the UK had national systems of innovation policies that were biased towards being 'mission-oriented', though in his assessment France had been considerably more successful in implementing policies of this nature. However, the mission/diffusion dichotomy proves to be very much a 'reduced form' of the multiple varieties of policy activities implemented and their design in different countries; nor does it make enough concessions to changes at the national level through time (Foray and Llerena, 1996; Cantner and Pyka, 2001). For instance, in Ergas (1987), 'mission-oriented' refers to programmes investing in radically innovative programmes and including centralised decision-making. However, centralised and decentralised organisation structures are not always equally efficient for 'mission-oriented' and 'diffusion-oriented' 
innovation policies and programmes. According to Foray and Llerena (1996), a diffusionoriented programme with decentralised coordination requires minimal technical capability and learning potential on the side of potential user firms and a high degree of perfection of decentralised coordination of policy-makers, where policy-implementers have information about the whole system. If these technical and organisational capabilities of firms, policymakers and policy-implementers are limited, then centralised coordination becomes more significant for implementing diffusion targets. Instead, to implement mission-oriented programmes with centralised coordination, a high capacity of central institutions to accumulate past experiences and know-how is required. Otherwise, decentralised coordination can be more effective for supporting the creation of new technologies, even those with mission-like properties (ibid.).

Moreover, other authors, especially public policy researchers, have tried to understand which policy instruments and what forms of policy implementation should be used to support certain innovation objectives in specific informational and institutional environments. Hence, they propose that policy design and implementation may depend on the objectives and type of response expected from firms (getting unique/different responses) as well as on the technological and policy environment (Sabatier, 1986; Bressers and O'Toole, 1998).

In particular, Bressers and O'Toole (1998) argue that to address policy networks (target populations) characterised by similar objectives among actors (strong cohesion), the most likely policy instruments to be chosen are those that provide additional resources to target groups and the freedom to opt for or against application of the instrument. In particular, in cohesive networks with intense interactions among actors, policy programmes are likely to provide subsidies, education and personal advice, and to be implemented by policy-makers or closeaffiliated organisations. Instead, in cohesive networks with weak intensity of actor interactions, policy programmes are expected to be implemented by intermediaries and to provide subsidies for investment and research as well as published mass-media information. To address networks characterised instead by conflicting objectives of actors (weak cohesion), the most likely instrument to be used is regulation, aimed at partial withdrawal of resources from the target group, to be implemented by policy-makers or closely related organisations.

Moreover, Sabatier (1986) proposed that top-down policies are better when research funds are very limited or there is primary interest in mean responses and the technological situation is moderately structured. In contrast, bottom-up policy approaches seem more appropriate in situations where there is no dominant technology but a large number of actors without power dependency, or there is primary interest in the dynamics of different local situations in which variety prevails. Hence, the type of policy tool or support provided ought to match not only the 
form of implementation, but also the objectives of the programme. In this manner, the three dimensions outlined in this study are first related.

Overall, the characteristics of the knowledge and innovation systems in which policy-makers aim at intervening are critical for the choice of the policy instruments, and organisational and implementation details: technical and coordinative capabilities of policy-makers, absorptive capabilities of firms, connectedness of policy networks, and policy objectives. As Callon et al. (1991b) argued, adequate project design depends on the analysis of the socio-technical networks involved in the process that policy aims to address. This means understanding policy programmes as well-run enterprises that coordinate different kinds of knowledge and organisations and that require extensive active involvement in diagnosing problems and designing solutions (Kooiman, 1993). However, the reason for changes through time and countries in the design, implementation and choice of policy instruments cannot be completely explained by learning or national styles (Peters, 2000; Blair, 2002). Policy programmes are launched within a specific policy paradigm, which shapes the way problems are defined, the type of solutions offered and the policies proposed (Mytelka and Smith, 2002).

By considering these three dimensions - objectives or type of knowledge and activities addressed, the forms of implementation, and the policy instruments or incentives provided - the policy analyst/evaluator is acknowledging the fact that a certain policy programme encourages specific knowledge interactions and learning. The existing national innovation system will evolve in response to the incentives put forward through innovation policies and programmes with specific objectives, involving particular management and delivery networks, and providing particular incentives. Thus, even though not describing the innovation system and its inner complex arrangements, these dimensions may allow mapping the interactions and activities that are being encouraged to develop and grow by policy-makers. Additionally, these dimensions may permit mapping the evolution of innovation policies, in terms of objectives and targets, design, implementation and incentives, and indirectly the evolution of the innovation systems themselves.

\section{Framework for mapping policy design}

This paper explores national and temporal diversity in the alignment of policy activities aimed at coordinating and enhancing the demand for and supply of innovative inputs and consequently at supporting management improvement and innovation in firms. In the literature, as noted above, the design of policy programmes is most often defined variously by the way implementation is organised, the type of support provided, and the objectives and targets 
addressed. Based on these categories, we propose a three-dimensional framework to analyse, over time and across countries, the design of policy programmes to encourage the alignment of objectives and activities of diverse actors involved in the demand for and supply of innovation inputs, and consequently the diffusion of new organisational and managerial capabilities.

Since a specific innovation policy is likely to lead to the implementation of several programmes with different design characteristics to achieve its goals, in this paper we will compare policies through time and across countries by analysing the main characteristics of the national portfolios of programmes designed and implemented in terms of the three proposed dimensions.

According to this three-dimensional framework, as represented in Figure 1, innovation policy programmes can be characterised by their type of objectives or knowledge structures addressed (vertical or horizontal development of knowledge and business-to-business interfaces), type of implementation (local or central), and the type of support provided (specific detailed or general).

[Figure 1 about here]

Type of knowledge objectives (Vertical versus horizontal dimension): Vertical programmes procure the development of new knowledge or increase the number of explicit interfaces in the business-to-business market. On the contrary, horizontal programmes tend to support awareness of firms and the diffusion of best-practices by supporting horizontal diffusion of existing knowledge and increasing the number of firms that use it and interact in specific ways in the business-to-business market. Despite the differences of terminology and meaning, vertical/mission and horizontal/diffusion are quite widespread categories in the innovation policy literature to capture the objectives or the targets of programmes and policies (Ergas, 1987; Foray and Llerena, 1996; Lall and Teubal, 1998). In this paper, we focus on diffusionoriented policies (in the meaning of Ergas, 1987) aimed at supporting the development of technological and management capabilities in France and in the UK. Using these two dimensions, each policy programme will be differentiated by its vertical or horizontal targets and objectives (in the meaning of Lall and Teubal, 1998).

Type of support (Specific versus general management support): This criterion takes into account both the type of public support or incentive provided and the type of performance addressed. Programmes providing firms with specific detailed incentives aim at supporting the development of similar capabilities and assume that the needs of firms are quite similar (e.g. in regard to IT adoption or transportation logistics, etc.). Programmes providing general support for firms instead usually privilege the diversity of the needs of firms. A general service or information capacity may be made available to firms, which can use this to develop particular capabilities and responses. These dimensions, related to policy instruments and tools, are less 
widely adopted in the innovation literature than those for the objectives. Still, a distinction between specific direct incentives (tangible) and capacity or services has been made in the policy literature (Sabatier, 1986; Schneider and Ingram, 1988, 1990; Jacoby and Schneider, 2001). In particular, capacity tools ".. assume incentives are not an issue, but there may be barriers stemming from lack of information, skills or other resources" (Schneider and Ingram, 1990: 517). Therefore, Jacoby and Schneider (2001) argue that there is a trade-off between particularized tangible benefits and collective goods or capacity. A similar type of distinction between specific and general policy tools has been proposed in some innovation studies to capture differences in types of innovative incentives (Teubal, 1997; Garofoli and Musyck, 2001).

Type of implementation (Local versus central programme implementation): The chosen implementation reflects the way the problem of providing support for firms is decomposed. Local programmes refer to those implemented by decentralised organisations, either public or private. These programmes are expected to use wider implementation structures and indirect means of monitoring policy delivery and implementation. On the contrary, central programmes refer to those directly implemented and monitored by the central ministry. Again, these dimensions are widely used in the innovation and policy literature to capture the main characteristics of programme implementation and management so as to differentiate the role of government in design, implementation and management, and the importance of the role of the network of actors in those processes. In particular, the policy literature refers to them as topdown and bottom-up approaches to policy implementation (Sabatier, 1986; Blair, 2002). These dimensions seem to affect symmetrically the interaction with private sector and the complexity of the implementation networks (Blair, 2002). In the innovation literature, Foray and Llerena (1996) make a similar distinction in the nature of programme implementation, but using a different term (centralised versus decentralised).

This three-dimensional framework will be used to analyse and compare over time the French and British public incentives for innovation and upgrading of managerial capabilities in firms, as well as the way that policy-makers were supporting the alignment of objectives and activities of national players towards innovation diffusion. 


\section{Methodology and data to explore the changing portfolio of policy activities in the UK and France}

\subsection{Data}

For the purposes of such analysis, a database was built of policy programmes supporting management improvement and innovation in firms, designed and financed by the industry ministries in the UK and France (the DTI and MINEFI respectively, according to their predominant recent titles), from the early 1980s until 2002.

Information on the British policy programmes was collected from the government expenditure plans of the DTI, DTI-related web pages and archives of the Financial Times and The Economist. Information on the French policy programmes was collected from reports of the Senat and the Assemblée Nationale to the "Projet loi de finances" for the departments of industry as well as of the small and medium enterprises, MINEFI-related web pages and several national reports on innovation issues, and the archives of Le Monde and L'Echos. Additionally, for both countries, several on-going reports on policy programmes, promotional leaflets, evaluation reports and reports of activities of several organisations were consulted. This process of data collection permitted building a dataset of 81 British and 68 French policy programmes supporting innovation and the development of new management capabilities in firms. Although a series of interviews allowed double-checking the significance of our database, ${ }^{3}$ this data collection exercise may still be biased towards programmes which received more advertising, political concern, higher budgets and mass media coverage. Given the similarity of the methodologies used to collect data in both countries, we expect that the potential bias affecting the French and the British data would be comparable.

\subsection{Variables}

Public programmes are understood as coordinating and rewarding individual and collective learning for a determined period of time in order to accomplish specific objectives. With the objective of understanding public incentives for management and innovation over time, policy programmes are characterised according to several design details. Table 1 below reports the variables created to describe the design of programmes.

[Table 1 about here]

\footnotetext{
${ }^{3}$ Extensive discussions of the content of this database of policy programmes were conducted with public servants in the departments responsible for their design and implementation.
} 


\section{Mapping policy activities supporting innovation in firms}

\subsection{Organisational dimensions of programmes}

To explore whether the three dimensions differentiate the design of policy programmes supporting business firms as well as the incentives they create, categorical principal component analysis is undertaken, using all variables describing the organisation and design of public support schemes, for the 149 observations (81 British and 68 French). Results show that 7 components ${ }^{4}$ explain $64 \%$ of the variance across programmes (Table 2). ${ }^{5}$ The spread of components underlines the diversity of programme designs. The values for Cronbach's Alpha for each factor are reported in the last column of Table 2 and suggest that the three proposed dimensions seem reliable factors to analyse all programmes.

[Table 2 about here]

1) The first factor is regarded as referring to the Horizontality of programmes, ${ }^{6}$ which is related to their objective of providing non-restrictive support for skills transfer and best-practice diffusion across a large number of firms. It includes general information and services to support capabilities development in firms, and relates to simpler forms of getting public support such as posting packaged information or internet access. It also relates to a certain degree of decentralisation in the implementation of programmes and to the participation of private organisations in the delivery of the support to firms.

2) The second factor considers General support. Instead of involving financial subsidies for the use of external technical services or for collaboration in research or technology diffusion, these programmes provide information and demonstration exercises, and consequently use standards and codes to support best-practice diffusion. The programmes tend to be implemented centrally using experts, and are delivered by different types of organisations.

3) The third factor relates to Central implementation and delivery of public support. It includes provision of similar public support across the country, mainly direct financial subsidies. It refers to central control and management of the implementation, instead of a decentralised implementation by local organisations that conform to standards.

\footnotetext{
${ }^{4}$ From the seventh component onwards, the additional percentage of variance explained is less than $5 \%$.

${ }^{5}$ These results are compatible with the results obtained from traditional factor analysis.

${ }^{6}$ By construction, these views about the meaning of the factors are deduced from the findings.
} 
4) The fourth factor is concerned with Vertical creation of policy capacity and not direct support for firms, though evaluation is undertaken. It includes the creation of a structure or organisation eventually linked with local actors to provide firms easier forms of getting public support.

5) The fifth factor relates to Incentives to market developments of new technical and business services. It includes central implementation through open-call procedures for collaborative proposals for adequate business-to-business services. These market encouragement exercises may also increase the existing policy capacity.

6) The sixth factor addresses Vertical knowledge development activities, aimed at supporting skills transfers through technology diffusion and the development of new codified knowledge. These activities include support for research and technology development and are generally implemented by the central administration and expert organisations, mainly public.

7) The seventh factor covers Efforts to improve the quality and adequacy of public services. It includes the requirement for policy providers to adopt standards as well as codification efforts aimed at developing tools to improve and monitor services. To a more limited extent, it also includes open calls addressed to local policy providers for them to rethink the needs of firms and their services.

The primary differences across programmes thus seem related to their horizontal or vertical objectives of knowledge diffusion, the degree of decentralisation of their implementation, and the generality or specificity of their support. These three proposed dimensions, with Cronbach's Alpha above 0.7 (Cortina, 1993), seem to be the most relevant factors to explain variance across programmes in supporting firms to adopt best-practices. Factors of 'service capacity creation', 'knowledge development', 'market encouragement' or 'public services improvement' seem to be better at differentiating programmes with a certain verticality in their objectives, and consequently using them for all the programmes appears less reliable than the three proposed dimensions.

\subsection{Typifying policy activities}

To visualise and understand differences in objectives and design of policy programmes aimed at supporting innovation in firms, a K-means cluster analysis was run using data on innovation policies for the two countries together and with data on each country individually.

When the 149 programmes are considered together, they tend to cluster in seven groups as follows: Awareness campaign programmes, Label creation programmes, Policy structure development programmes, Central financial subsidies programmes, Local support framework programmes, Local services structure programmes and Flagship programmes. Instead, when 
looking at each country separately, results suggest that the best typology of programmes should be based on six clusters only. ${ }^{7}$ A summary of the results is shown in Table 3. Table 1 and 2, in the Annex, report respectively programmes in each cluster and the profile of each cluster. ${ }^{8}$

[Table 3 about here]

In France, Policy structure development and central financial subsidies programmes collapsed into a unique group of programmes aimed at Market encouragement. In the UK, Local service structure and Local support framework programmes are collapsed into Local services programmes aimed mainly at promoting information and advice services.

Despite the presence of some national peculiarities, the seven clusters seem to group together public support schemes that have a common pattern of design and objectives. To gain insight into the overall classification and the national specificities, the characteristics of each cluster in France and in the UK as well as its three-dimensional design space will now be described.

The Label creation cluster includes programmes that address only intermediate organisations and involve codification exercises. The outcomes of these programmes are standards and tools related to the use of some specific technological or managerial and/or the creation of new organisations that become responsible for leading knowledge development, best-practice promotion and accreditation of those best-practices and standards; for example the British Quality Foundation or the Mouvement Français pour la Qualité. These programmes are implemented by groups of technical and professional organisations that are experts on the subject. Thus, programmes included in this cluster combine the dimensions of centrality of policy implementation with support for an increase in vertical business-to-business market interfaces.

The Awareness diffusion programme cluster includes campaigns that provide information and demonstration exercises on the benefits of the adoption of a particular management technology together with initial help with adoption problems. These programmes generally target a great number of firms with the objective of raising awareness of the existence of public support and new best-practices. This cluster is situated at the opposite extreme to Label creation, since these programmes generally tend to use established codes to promote the adoption of best-practices;

\footnotetext{
${ }^{7}$ For each case, we chose the number of clusters that maximize the number of variables (related to the design of programmes) that are significantly different across clusters.

${ }^{8}$ For a detailed characterisation of programmes in the dataset, please consult the research thesis by the first author (Bodas Freitas, 2006).
} 
however sometimes they also include codification activities to develop information packs for providing firms with information. Their delivery tends to be local or electronic, which facilitates access from firms, although customisation is not usually possible. Their implementation tends to be monitored directly by central administrations. Overall, the dominant dimensions of Awareness diffusion programmes tend to be central delivery of general support for horizontal diffusion of existing knowledge and market interfaces. ${ }^{9}$

The Central financial subsidies cluster identifies programmes that provide financial subsidies to encourage the adoption of existing best-practices or the development of new best-practices, technologies or business-to-business interactions. In these programmes, firms need to apply to get financial support. The degree of possible customisation of policy support to the needs of firms is typically not very high because the project a firm applies with has to be related to the theme of the specific programme. The implementation and delivery of these programmes tend to be directly monitored by central ministries. Very few different types of organisations participate in delivery, although a large number of private organisations may be directly involved in the support for firms. Thus, these Central financial subsidies programmes are found at the interaction of the dimensions of central implementation, specific support for horizontal diffusion or for a vertical increase of knowledge and market interactions. ${ }^{10}$

In the Local support framework cluster, we find programmes aimed at encouraging best-practice diffusion and skills transfer. These provide financial subsidies, advice and technological services to firms on a local basis. They are implemented by a network of private policy implementers with the power to accommodate the established support framework to address the needs of local firms. Therefore, the degree of customisation to the needs of firms is high and there are usually several types of organisations participating in the delivery, many of which are private. Programmes belonging to this cluster tend to be situated at the interaction between local

\footnotetext{
${ }^{9}$ In the UK, the implementation of diffusion campaigns is sometimes contracted out, despite the DTI continuing to monitor programme delivery and outcomes. In France, most campaigns tend to be implemented with the local services structure and relying on expert organisations.

${ }^{10}$ In France, Central financial subsidies were used mainly after the mid-1990s, to encourage technological development in certain areas as well as collective initiatives for the diffusion of new technological and management capabilities in firms. They tended to involve open calls for collaborative projects proposed by a group of firms and, usually, a professional or sector organisation to guarantee the diffusion of the financed project outcomes across their customers. In the UK, Central financial subsidies programmes were mainly launched during the 1980s and in the late 1990s for financially encouraging firms to adopt best-practices. Their delivery and implementation, which tended to be contracted out to consultants, was often directly controlled by the DTI.
} 
implementation and horizontal diffusion of best-practice, and they refer mostly to specific advice and financial support. ${ }^{11}$

The cluster of Local services structures includes programmes providing firms with local structures that can supply complementary information and advice services. They are implemented by local policy providers, which have been previously created or have won a call for the provision of management and technology support services to firms. The central administrations may monitor the implementation of the structure or the open-call procedure, but not the delivery of local business services provided by that structure to firms. Local services structures programmes are found at the interaction of local implementation and general support for best-practice diffusion. They differ from the Local support framework in being mainly a gateway to the local framework and revealing the early vertical central support that permits the development of those market interfaces in the local business-to-business market.

In the Policy structure development cluster, programmes generally aim at improving the quality of services provided to firms. They support the codification of knowledge on the needs of firms held by the policy-providers (intermediate organisations) or the development of a new structure in order to provide firms with more adequate and updated supporting services matching their needs. Therefore, in terms of the benefit to firms they are quite similar to the Local services structures, despite the aim of these programmes usually being to install a new structure rather than complement the existing one. Programmes aimed at Policy structure development are found at the interaction of dimensions of central implementation, specific support and vertical interfaces in the business-to-business market. ${ }^{12}$

${ }^{11}$ In the UK, this cluster involves mainly local customised services of advice, information and diagnostics, which became available to firms from the mid-1990s. From that time, the DTI contracted the provision of a defined set of services with local policy providers (i.e. Business Links) that could be customised for better addressing the specific needs of local firms. The DTI also abandoned direct control of delivery and implementation by instead requiring local providers to meet certain standards. In France, programmes in the Local framework support cluster are generally approved by the Contrat plan Étatrégion and entail financial subsidies for advice and technological services to be provided and approved locally.

${ }^{12}$ In the UK in the early 1980s, the DTI was solely responsible for establishing the support structure, while during the 1990s, it tended to be implemented through an open call that provided financial subsidies for local partnerships proposals in a portfolio of support services to address the DTI's policy objectives. In France, as most of the local policy structure was developed in the early 1980s, most programmes that fell into this category referred to central administration agreements or to financial support for collaborative projects with the existing local organisations. Other similar types of projects, aimed at encouraging local policy-deliverers to rethink their services in relation to the actual needs of firms and 
Finally, programmes aimed at introducing a new topic or objective of policy are included in the Flagship cluster. These programmes aim at diffusing best-practices, encouraging the development of markets for new technologies and services, and developing tools to support information diffusion and to solve technological problems. They generally create a capacity to provide information and advice services and demonstration exercises to a great number of firms. Given the component of advice services, there is a certain degree of customisation to the needs of firms. They also tend to involve codification exercises aimed at developing tools to support management and technology problems of firms as well as new ambitious technologies. Consequently, several types of support are used, such as information, research subsidies and advice services to achieve programme objectives. These programmes tend to be implemented through experts and with local policy deliverers. A great number of different types of organisations both public and private participate in their implementation and delivery. Hence, the Flagship cluster comprises a mix of all dimensions and programmes objectives, as they try to implement structural organisational change, including the creation of new system capabilities. $^{13}$

This detailed analysis of the seven clusters permits associating each cluster with a specific design space of programmes across our three proposed dimensions. Table 4 reports the main dimensions of clusters broken down by country, based on the previous discussion of the specific characteristics of programmes in each cluster.

[Table 4 about here]

This analysis shows that policy-makers try to enhance best-practice diffusion through the implementation of several types of policy programmes, with a specific three-dimensional design, in order to leverage coordination of demand for and supply of innovative inputs.

eventually to develop new services, were included in the Central financial subsidies and/or the Local service structure clusters.

${ }^{13}$ In the UK, especially from the mid-1990s and for accountancy purposes, the DTI started structuring its policies around Flagship programmes to address a policy priority in the domain of the introduction and diffusion of a new technology or management best-practice. Generally, flagship campaigns entail a series of very different sub-activities, and the role the DTI plays differs across them. In France however, Flagship campaigns tend to involve the creation of an agency, which becomes responsible for information diffusion, training and demonstration activities and for involving several other local and professional organisations. For this reason, some French Flagship programmes were also included in the Label creation or Awareness diffusion clusters. 
Programmes in each cluster provide (different) incentives to different types of actors for learning and innovation. In particular, policy structure development, label creation and some of the central financial subsidies encourage different types of suppliers of innovative inputs (local policy providers, and technical, professional, expert and standards-setting organisations) to develop specific knowledge activities. Local support framework, local services structure, awareness diffusion and some of the central financial subsidies aim at providing different incentives for innovation to firms (eventually with different innovative capabilities). Flagships aim at gathering general commitment by policy-providers, knowledge providers and firms towards a similar broad innovative objective. Awareness diffusion and label creation programmes tend to have lower budgets than local support framework, local services structure and most of the flagships and central financial subsidies.

Additionally, based on a taxonomy of public support for innovation in firms, this analysis can abstract from national differences in style and context of policy-making and consequently compare national specificities and their rationales. Differences in the nature of the national public Local support framework as well as differences in the frequency of using Policy structure development reveal national specificities in the development of the local policy delivery structure, associated with the characteristics and objectives of the national processes of public reform undertaken in each country, as will be discussed later. Instead, differences in the level of use of Flagship and of Awareness diffusion programmes seem mainly to reflect distinctive marketing strategies and procedures of reporting of central administration activities (which may also have introduced some bias into our data) as well as different forms of implementation of similar policy objectives.

\section{Mapping patterns of alignment of policy activities and of organisational design of public support over time}

\subsection{Evolution of policy design}

In this section, the national portfolios of innovation policy programmes are explored over time to assess the national patterns of alignment of innovation objectives undertaken by policymakers. In particular, four periods, characterised by different public investment priorities, types of support provided and organisation of public support, are considered: 1983-87, 1988-94, 1995-98 and 1999-2002. ${ }^{14}$

\footnotetext{
${ }^{14}$ In the UK, 1988 marks the year in which most public support schemes, previously centralised in the DTI head office, were put together under Enterprise Initiatives, implemented with the support of the DTI Regional Offices. 1995 marks the year in which public business support starts to be mainly implemented
} 
In our dataset, most of the British programmes do not last for more than one period. On the contrary, most of the French programmes launched in the first and second periods were still active in the final period. Hence, we have corrected the dataset for the persistence of programmes (i.e. each programme that lasted to the next period was reintroduced as a programme of that following period). For a deeper understanding of the national evolution pattern, logistic regressions for each variable describing the design of programmes on the independent variables Period and Country were computed using the corrected dataset, to analyse the evolution of the national portfolios of innovation policies. Results of the estimation of the logistic regressions are summarised in Table $5 .{ }^{15}$ For each dependent variable, the table reports whether changes are significantly explained by (differences in) the two independent variables, Period and Country. To understand these results further in the light of the three design dimensions proposed, logistic regressions were run for each variable describing the three dimensions as relating to the independent variables Country and Period. Results are summarised in Table 6.

\section{[Tables 5 and 6 about here]}

Results suggest that differences between countries in the portfolio of innovation activities seem to exist in each period in the type of support provided, activities supported, degree of customisation of public support, degree of direct control and management of implementation and level of decentralisation of policy implementation.

In particular, differences are found in the use of financial subsidies for collaboration, technology adoption and for research (mostly in France), as well as in the use of codified packs of knowledge to provide information and advice services (mostly in the UK). These specific differences mainly reflect different forms of reporting of activities and the fact that British liberal policy-making focused on the provision of information and on sponsored services rather than direct financial benefits. Moreover, more direct control and more centralised policy implementation is undertaken in the UK than in France. The requirement to conform to standards seems more commonly used in the UK. However, there are almost no differences in the type of procurement or in the objectives of the portfolios, except for the technology

by local private organisations. From 1999, the creation of the DTI Small Business Service, as a 'next step' agency, began to be planned with a specific target of improving the quality and homogeneity of public business support, and the coordination of local and regional policy organisations. In France, these periods roughly coincide with the four generations of CPER: 1984-88, 1989-93, 1994-99 (1994-1998, extended to 1999), and 2000-2006.

${ }^{15}$ Results for uncorrected data were similar but usually sparser in terms of significant differences. 
diffusion objective. Hence, differences are found in the way national policy-makers align innovation activities, i.e. use diverse implementation structures, and address different types of actors to provide firms with a rather varied portfolio of financial and intangible incentives. In particular, a greater alignment of private local policy activities and a preference for the provision of intangible incentives to firms are observed in the UK.

Results in Table 5 also suggest that time contributes to explaining some similarities in the evolution of portfolio of national innovation policies in the two countries, especially changes in the forms of implementation, procurement and objectives. In particular, central open calls have been increasingly used as a procedure to implement programmes; consequently central implementation and the involvement of other organisations in the design of public support became more frequent. Moreover, procurement of new knowledge, to support the development of new capabilities in firms or the improvement of the support services to firms provided by policy implementers, has also been more often included in programmes. Hence, improving the quality of public services and encouraging market developments in business-to-business services have increasingly become objectives aimed at by programmes, contrary to the objective of diffusing consultancy benefits. Thus, despite some national differences in the support for innovation activities, both systems of national innovation policies have evolved towards the alignment of similar activities and knowledge objectives, using similar implementation procedures to align activities of different suppliers of innovative inputs.

In Table 6, we find that differences in national portfolios of programmes in each period are primarily explained by national differences in the dimensions of Local/Central implementation and General/Specific support. ${ }^{16}$ Overall, results suggest that differences between the evolution of the French and British portfolio of programmes may be partly explained by their apparent evolution towards different 3-dimensional design spaces, particularly in implementation and type of support. Figure 2, representing the share of each type of programme in the overall portfolio of policies functioning in the period, ${ }^{17}$ suggests that the mid-1990s was the turning point in the design of national portfolios as well as their differences.

[Figure 2 about here]

\footnotetext{
${ }^{16}$ Using the original dataset, when analysing the differences in the evolution of policy design, we find national differences in the use of local forms of implementation of newly launched programmes. Still, similar trends are observed in both countries related to the horizontal/vertical objectives of the new launched programmes in later periods.

${ }^{17}$ The share is computed on the basis of a count of programmes.
} 
Until the mid-1990s, the French portfolio of innovation policies concentrated more on the use of local support frameworks and local services structures, while the British showed a greater reliance on label creation and central financial subsidies. Throughout the 1990s, the British portfolio of innovation policies seemed to rely more than the French on investment in policy structure development and flagships, and to a lesser extent on awareness diffusion. After the mid-1990s, differences in the use of label creation and in the reliance on a local services structure almost disappeared, though differences in the intensity of use of local support frameworks persisted. The French portfolio started being more reliant than the British on central financial subsidies, but to encourage new business-to-business and technological developments rather than to address pure horizontal diffusion. However, in both countries, the importance of investments in label creation, in raising firms' awareness of best-practices, and in business-tobusiness market encouragement rose from the mid-1990s in the national portfolio of policy activities. In addition, after 1999, except for the local support framework, most of the differences appeared to attenuate. ${ }^{18}$

Thus, in the UK, the early focus on central knowledge development activities of experts and their diffusion as well as on provision of central financial and information to firms has switched towards the alignment of different local knowledge activities and integration with central ones, as well as towards the provision of non-financial incentives for innovation to firms. In France, the need to align multiple local knowledge development activities, and with national actors, obliged an increased reliance on the provision of central incentives to interaction among suppliers towards common activities, and greater efforts to support management through labels and information.

In particular, in the UK, horizontal programmes have become increasingly locally implemented and aimed at providing firms with general support, as management best-practice became one of the main themes of policy from the early 1990s. In France, however, few new horizontal programmes were launched in the 1990s, but the previously existing decentralised schemes remained available to firms, supporting them with the development and diffusion of new technologies. In both countries, as public support for innovation was mainly decentralised, the launching of programmes with some verticality in their objectives of knowledge creation and market interfaces increased, using a mix of specific and general support through open calls and codified tools. In particular, efforts in both countries were directed towards increased encouragement of new market development through open calls to local and professional

\footnotetext{
${ }^{18}$ As seen before, differences in the use of Flagships and consequently the implementation of Awareness diffusion programmes might be due to the way these are implemented in each country, possibly introducing some bias into our sample.
} 
business services providers, as well as the development of tools to monitor public business services provision or to support management capabilities of firms. Nevertheless, the style and the underlying objectives were somewhat different between the two countries.

\subsection{Similarities and differences in the evolution of policy alignment strategy}

As in other OECD countries, to minimise direct government intervention in firms and acknowledge new views on the sources of national competitiveness, both the French and the British public business support became more non-financial each time, more carried out through network governance, and increasingly concerned with innovation (OECD, 1993; Mytelka and Smith, 2002; Levet, 2003). The competitiveness of national economies in global markets is increasingly understood as a specific adaptive capability of national firms rather than some average behaviour of the most capable firms (Andersson, 1998; Metcalfe and Georghiou, 1998; OECD, 2004). In this context of policy focus on the development of firms' absorptive and adaptive capabilities, and of strong interactions among suppliers of innovative inputs, such changes in policy design and implementation would be those expected by Sabatier (1996) and Bressers and O’Toole (1998).

Consequently, as already observed, the public sector in both countries increasingly became a provider of market incentives to new and/or better business-to-business services and of signals relating to new market and technological opportunities. Nevertheless, differences in the evolution of the design of the French and the British policy programmes did exist and, to a certain extent, seemed to reflect the early national differences as well as the rules dictated by the politics of national public sector reform (OECD 1993, 2000a,b,c). Hence, the form of alignment of innovation activities, measured by the design of the national portfolio of policy activities, evolved in both countries as national players and their objectives, characteristics and technological and market context evolved.

In particular, in France, from the 1980s, under a political commitment to decentralisation of budget and responsibilities, public support for innovation and management capabilities of firms came to be implemented at regional and local level by an increasing number of organisations. Both the portfolio of policy instruments directly benefiting firms and the way they were delivered did not seem to change much from the mid-1980s. Changes that are observed, from the mid-90s, were related to newly launched programmes aimed at complementing and supporting the emergence of new markets and new technologies, as well as at signalling the areas that local frameworks should be used for. These newly launched programmes, mostly centrally organised, aimed at encouraging networking and collaboration among policy providers to improve accessibility of public business support for firms and at decreasing its complexity, along with encouraging the development of technological and business-to-business services 
together with best-practice technologies. Indeed, several evaluations have suggested the need to support collaboration and interaction among the multiple suppliers of innovative inputs towards common innovative goals and activities, including improving the efficiency of the policy delivery system (Marini, 2001; Levet, 2003).

In the UK, the introduction of value-for-money and 'hands-off policy execution' principles in the public sector delayed the process of decentralisation of public business support, through forcing the government to dismantle the ministerial regional offices and to contract out the provision of some sorts of sponsored services. The outsourcing of policy execution to a local private infrastructure of policy providers seems to have both required and provoked changes in the design of policy programmes, in the type of support provided to firms, and in the number of private organisations delivering support to firms. Thus, while until the mid-1990s most horizontal public support consisted of specific types of support centrally delivered, from the mid 1990s a change can be observed towards more local implementation and the provision of general support. In particular, this change towards general support was supported by evaluators of the Consultancy Initiative, which also stressed the importance of local advisers in the diagnoses and implementation of management and technological solutions (PA, 1995). Nevertheless, centrally implemented programmes were still launched. They were aimed at supporting further developments in business-to-business services and in homogeneity of quality of local public business, as well as at encouraging the development and diffusion of awareness of new best-practices. This is in line with the results from evaluation of publicly sponsored services provided by local policy providers (Business Links), which were found to lack visibility and homogeneity of quality, and type of support. Moreover, information and advice were the highest rated and personal business advice and problem diagnostics were now among the least used services (Campbell, 1997; PACEC, 1999; Brown, 2000).

To visualise the national pattern of alignment of innovation objectives undertaken by policymakers across the three proposed design dimensions, we compute the share of each design dimension in the overall portfolio of the French and the British programmes functioning in each period, as well as in the group of the newly launched programmes. These graphs, shown in Figure 3, suggest that there are static and dynamic national differences in the form in which policy-makers tried to align policy activities and innovation objectives over time. As seen before, the alignment pattern evolves as the players and the objectives in the innovation policy structure evolve. However, the speed of change of the national alignment patterns might not be equal across countries; indeed, the French design space for the portfolio of innovation policy activities has apparently changed less than the British one. 
[Figure 3 about here]

\section{Overview and conclusions}

The aim of this paper has been to identify and test empirically a framework for comparing national incentives supporting diffusion of best-practices in innovation, which has also explored national and temporal diversity in the alignment of policy activities aimed at coordinating and enhancing demand for and supply of innovative inputs. For this purpose, we used a sample of French and British programmes supporting management improvement and innovation in firms between the early 1980 s and 2002 .

This paper has shown that the design of innovation policy programmes can be synthesised into three dimensions related to knowledge objectives, implementation and type of support.

(1) Vertical programmes procuring new knowledge or business-interactions address a limited number of actors and tend to be centrally monitored and implemented. Horizontal programmes, diffusing existing best-practices, instead provide firms directly with information, advice and financial support, and their organisation varies according to the type of support provided and how the delivery is envisaged.

(2) Local implementation of policy programmes tends to provide a known framework of support, which may take the form of customised services of information, technology advice or financial help. The central implementation of horizontal programmes is instead mainly associated with provision of support for specific projects related to either vertical or horizontal increase of market interfaces. Central implementation is also associated with awareness raising, an area in which it is difficult to create incentives for private organisations to exert effort.

(3) General support is associated with information and advice services, provided by local decentralised and electronic centralised advice centres to address the different needs of firms to innovate and renew their capabilities. Support for specific projects is associated with the provision of financial subsidies, which may or may not be directly controlled by central administrations.

During the 1980s and 1990s, the form of alignment of innovation activities undertaken by policy-makers evolved differently across the three-dimensional design space in the two countries. These changes reflected adjustments to meet new objectives, characteristics of the national players in the demand for and supply of innovative inputs, and the politics of publicsector reform. Nevertheless, in both countries, policy-makers increasingly focused on launching 
vertical programmes to improve the quality of public support for firms as well as to encourage new market, technological and managerial opportunities, as direct public intervention became less desirable and as semi-public or private business-to-business services were recognised as good suppliers of innovative inputs to firms.

Despite some similar trends found across countries, the alignment of incentives and objectives of national players towards innovation depends on the present and past specificities of these national innovation systems and their interlinkages. By permitting the characterisation of policy schemes in terms of selective/general incentives, diffusion/development objectives and investments in central/decentralised organisations, the framework presented here may serve for policy-makers to evaluate whether the design of a programme is the most suitable for addressing its objectives, and how far their current portfolio of schemes does so. 


\section{References}

Andersson, T., 1998. Managing a systems approach to technology and innovation policy. STI Review 22, 10-28.

Blair, R., 2002. Policy tools theory and implementation networks: understanding state enterprise zone partnerships. Journal of Public Administration Research and Theory, 12 (2), 161-190.

Bodas Freitas, I.M., 2006. Diffusion of quality and management capabilities in France and in the UK. Unpublished PhD Thesis, SPRU, Sussex University, UK.

Bressers, H.T.A., O’Toole, L.J., 1998. The selection of policy instruments: a network-based perspective. Journal of Public Policy 18(3), 213-239.

Brown, K., 2000. Small businesses voice concern over red tape: survey only 8 per cent happy with support services. Financial Times, 20 October.

Callon, M., Courtial, J.P., Crance, P., Laredo, P., Mauguin, P., Rabeharisoa, V., Rocher, Y.A., Vinck, D., 1991a. Tools for the evaluation of technological programmes: an account of work done at the centre for the sociology of innovation. Technology Analysis and Strategic Management, 3(1) 3-41.

Callon, M., Laredo, P., Rabeharisoa, V., 1991b. Des instruments pour la gestion et l'évaluation des programmes technologiques: le cas de L’AFME. In: De Bandt, J. (Ed.), L’Évaluation Économique de la Recherche et du Changement Technique, Paris, Editions du CNRS.

Campbell, K., 1997. New vision for Business Links. Financial Times, 7 October.

Cantner, U., Pyka, A., 2001. Classifying technology policy from an evolutionary perspective. Research Policy 30(5), 759-775.

Cortina, J. M., 1993. What is coefficient alpha? An examination of theory and applications. Journal of Applied Psychology, 78, 96-104.

Cowan, R., Foray, D., 1997. The economics of knowledge codification and diffusion. Industrial and Corporate Change 6(3), 595-622.

David, P.A., Foray, D. 1996. Information distribution and the growth of economically valuable knowledge: a rationale for technological infrastructure policies. In: Teubal, M., Justman, M., Zuscovitch, E. (Eds.), Technological Infrastructure Policy: an international perspective. Kluwer Academic, Amsterdam.

Ergas, H., 1987. The importance of technology policy. In: Dasgupta, P., Stoneman, P. (Eds.), Economic Policy and Technological Performance. Cambridge University Press, Cambridge.

Foray, D., Llerena, P., 1996. Information structure and coordination in technology policy - a theoretical model and two case studies. Journal of Evolutionary Economics 6, 157-173.

Furtado, A.T., Suslick, S.B., Pereira, N.M., Freitas, A.G., Bach, L., 1999. Assessment of direct and indirect effects of large technological programmes: Petrobás deepwater programme in Brazil. Research Evaluation 8(3), 155-163. 
Garofoli, G., Musyck, B., 2001. Innovation policies for SMEs in Europe: towards an interactive model? Regional Studies, 35(9), 869-872.

Goldman, M., Ergas, H., Ralph, E., Felker, G., 1997. Technology institutions and policies, their role in developing technological capability in industry. World Bank Technical Paper 383.

Jacoby W.G., Schneider, S.K., 2001. Variability in state policy priorities: an empirical analysis. Journal of Politics, 63(2), 544-568.

Justman, M., Teubal, M., 1996. Technological Infrastructure Policy (TIP): creating capabilities and building markets. In: Teubal, M., Justman, M., Zuscovitch, E. (Eds.), Technological Infrastructure Policy: an international perspective. Kluwer Academic, Amsterdam.

Kooiman, J. (Ed.), 1993. Modern Governance, New Government-Society Interactions. Sage, London.

Lall, S., Teubal, M., 1998. 'Market-stimulating' technology policies in developing countries: a framework with examples from East Asia. World Development 26(8), 1369-1385.

Larsen, M.T., von Tunzelmann, N., 2006. When non-markets fail: the role of public science in the development of generic technology. Paper for DRUID-DIME Academy Winter Conference, Denmark, Jan.

Levet, J.-L., 2003. Les aides publiques aux entreprises: une gouvernance, une stratégie. Commissariat général du Plan. Paris, La Documentation Française.

Lipsey, R.G., Carlaw, K., 1997. Technology policies in neo-classical and structuralistevolutionary models. STI Review 22, Special Issue on 'New Rationale and Approaches in Technology and Innovation Policy'. OECD.

Marini, P., 2001. Rapport général sur le projet de loi de finances pour 2002, tome III - Les moyens des services et les dispositions spéciales (deuxième partie de la loi de finances), Sénat, $n^{\circ} 86$ Annexe 12 - Industrie et $n^{\circ} 87$ Annexe 13, Petites et moyennes entreprises, commerce et artisanat.

McGowan, F., Radosevic, S., von Tunzelmann, N. (Eds.), 2004. The Emerging Industrial Structure of the Wider Europe. Routledge, London.

Metcalfe, J.S., 2001. Institutions and progress. Industrial and Corporate Change 10(3), 561-586.

Metcalfe, J.S., Georghiou, L., 1998. Equilibrium and evolutionary foundations of technology policy. STI Review 22, Special Issue on 'New Rationale and Approaches in Technology and Innovation Policy', 75-100. OECD.

Metcalfe, J.S., Ramlogan, R., 2005. Competition and the regulation of economic development. Quarterly Review of Economics and Finance 45(2-3), 215-235.

Musgrave, R.A., 1959, The Theory of Public Finance. McGraw-Hill, New York.

Mytelka, L.K., Smith, K., 2002. Policy learning and innovation theory: an interactive and coevolving process. Research Policy 31(8-9), 1467-1479. 
Najmabadi, F., Lall, S., 1995. Developing industrial technology, lessons for policy and practice.

A World Bank Operations Evaluation Study.

OECD, 1993. Public management developments: survey 1993. OECD, Paris.

OECD, 2000a. Issues and developments in public management: survey 1996-1997 on the United Kingdom. PUMA OECD.

OECD, 2000b. Issues and developments in public management: survey 1996-1997 France. PUMA OECD.

OECD, 2000c. Public management developments in France: Update 1998. PUMA OECD.

OECD, 2004. Science, Technology and Industry Outlook, OECD.

O’Toole, L.J., 1986. Policy recommendations for multi-actor implementation: an assessment of the field. Journal of Public Policy, 6(2), 181-210.

PA, Cambridge Economic Consultants, 1995. Evaluation of DTI-funded TEC Services. DTI, HMSO.

PACEC, 1999. Business Links Value for Money Study. Public and Corporate Economic Consultants, Business Links Directorate DTI.

Peters, B.G., 2000. Policy instruments and public management: bridging the gaps. Journal of Public Administration Research and Theory, 10(1), 35-47.

Sabatier, P., 1986. Top-down and bottom-up approaches to implementation research. Journal of Public Policy, 6, 21-48.

Schneider A., Ingram, H., 1990. Behavioral assumptions of policy tools. Journal of Politics, $52(2), 510-529$.

Schneider, A., Ingram, H., 1988. Systematically pinching ideas: a comparative approach to policy design. Journal of Public Policy, 8, 61-80.

Teubal, M., Andersen, E., 2000. Enterprise restructuring and embeddedness: a policy and systems perspective. Industrial and Corporate Change 9(1), 87-111.

von Tunzelmann, N., 2003. Historical coevolution of governance and technology in the industrial revolutions. Structural Change and Economic Dynamics 14, 365-384.

Wegloop, P., 1995. Linking firm strategy and government action: towards a resource-based perspective on innovation and technology policy. Technology in Society 17(4), 413-428. 
Table 1: Variables used to describe programme design and organisation

\begin{tabular}{|c|c|c|c|}
\hline & Description of the variable & Name of the variable & Type of variable \\
\hline Time & Period in which the programme is launched & Period & $\begin{array}{l}\text { Categorical } \\
(4 \text { classes })\end{array}$ \\
\hline \multirow{5}{*}{$\begin{array}{l}\text { Actors } \\
\text { Addressed }\end{array}$} & It only addresses intermediate organisations & Intermediate org & Dummy \\
\hline & Does it provide a direct benefit to firms? & Not direct benefit & Dummy \\
\hline & \begin{tabular}{|l}
$\begin{array}{l}\text { Addressed actors - number of restrictions } \\
\text { (size, industry, other, not directly to firms) }\end{array}$ \\
\end{tabular} & Restrictions to access & $\begin{array}{l}\text { Categorical } \\
(4 \text { classes })\end{array}$ \\
\hline & $\begin{array}{l}\mathrm{N}^{\mathrm{o}} \text { of eligible population that may benefit from the } \\
\text { programme outcomes }\end{array}$ & Eligible population & $\begin{array}{l}\text { Categorical ordered } \\
\quad(6 \text { classes })\end{array}$ \\
\hline & $\begin{array}{l}\text { How firms are expected to benefit from the programme } \\
\text { (applying, visiting a local centre, phoning, accessing } \\
\text { internet, they are contacted) }\end{array}$ & Forms of access & $\begin{array}{l}\text { Categorical } \\
(5 \text { classes })\end{array}$ \\
\hline \multirow{5}{*}{$\begin{array}{l}\text { Type of benefit } \\
\text { for firms }\end{array}$} & Financial subsidies & Subsidies & Dummy \\
\hline & Information & Information & Dummy \\
\hline & Advice Services & Services & Dummy \\
\hline & Demonstration exercises & Demonstration & Dummy \\
\hline & Packs of knowledge & Codes & Dummy \\
\hline \multirow{4}{*}{$\begin{array}{l}\text { Activities and } \\
\text { capabilities } \\
\text { supported by } \\
\text { the scheme }\end{array}$} & Research & Research & Dummy \\
\hline & Organisational and managerial capabilities & Org. management & Dummy \\
\hline & Technology adoption & Technology & Dummy \\
\hline & Collaboration & Collaboration & Dummy \\
\hline \multirow{3}{*}{$\begin{array}{l}\text { Customisation } \\
\text { of public } \\
\text { support to } \\
\text { firms' needs }\end{array}$} & Similar type of public support across the country & Similar country & Dummy \\
\hline & $\begin{array}{l}\text { Can local providers customise the support framework, } \\
\text { which has been approved centrally? }\end{array}$ & Local orientation & Dummy \\
\hline & $\begin{array}{l}\text { Is the support customised to firms' needs? (mostly, } \\
\text { partly, no) }\end{array}$ & Customisation & $\begin{array}{l}\text { Categorical ordered } \\
(3 \text { classes })\end{array}$ \\
\hline \multirow{9}{*}{$\begin{array}{l}\text { Organisation of } \\
\text { programme } \\
\text { Implementation } \\
\text { and the role of } \\
\text { central } \\
\text { departments }\end{array}$} & $\begin{array}{l}\text { Role of the central ministry in the control and } \\
\text { management of Implementation and Delivery }\end{array}$ & Central Management & Dummy \\
\hline & $\begin{array}{l}\text { Do other organisations participate in designing the } \\
\text { programme support details? }\end{array}$ & Other org design & Dummy \\
\hline & Central calls for implementation projects & Calls & Dummy \\
\hline & Implementation by central departments alone & Central Implementation & Dummy \\
\hline & Implementation by central departments with experts & With experts & Dummy \\
\hline & Central implementation with local organisations & With local actors & Dummy \\
\hline & $\begin{array}{l}\begin{array}{l}\text { Implementation by a network of local organisations or } \\
\text { contractors }\end{array} \\
\end{array}$ & Network local org & Dummy \\
\hline & Level of decentralisation of programme's organisation & Decentralisation & $\begin{array}{l}\text { Categorical } \\
(4 \text { classes })\end{array}$ \\
\hline & Are policy implementers requested to adopt standards? & Requirement standards & Dummy \\
\hline \multirow{4}{*}{$\begin{array}{l}\text { Forms and } \\
\text { responsibilities } \\
\text { for delivery of } \\
\text { public support }\end{array}$} & Forms of Delivery (central, local, electronic) & Delivery & $\begin{array}{l}\text { Categorical } \\
\text { (3 classes) }\end{array}$ \\
\hline & $\begin{array}{l}\text { Number of private organisations delivering the public } \\
\text { support }\end{array}$ & Private org & $\begin{array}{l}\text { Categorical ordered } \\
\quad(5 \text { classes })\end{array}$ \\
\hline & \begin{tabular}{|l}
$\begin{array}{l}\text { Number of public organisations delivering the public } \\
\text { support }\end{array}$ \\
\end{tabular} & Public org & $\begin{array}{c}\text { Categorical ordered } \\
\text { (3 classes) }\end{array}$ \\
\hline & $\begin{array}{l}\text { Number of different types of organisations in the } \\
\text { delivery }\end{array}$ & Different Types org & $\begin{array}{l}\text { Categorical ordered } \\
\text { (3 classes) }\end{array}$ \\
\hline
\end{tabular}




\begin{tabular}{|c|c|c|c|}
\hline Continuation & Description of the variable & Name of the variable & Type of variable \\
\hline \multirow{4}{*}{ Procurement } & Knowledge on public business support delivery & Delivery knowledge & Dummy \\
\hline & Management knowledge & Managing knowledge & Dummy \\
\hline & Creation of new organisation & New org. & Dummy \\
\hline & Development of new services capacity & New services capacity & Dummy \\
\hline \multirow{9}{*}{$\begin{array}{l}\text { Macro } \\
\text { Objectives of } \\
\text { programmes }\end{array}$} & Demonstrate benefits of consultancy & Consultancy benefits & Dummy \\
\hline & Raise of awareness of public services & Awareness & Dummy \\
\hline & Best-practice diffusion & BP diffusion & Dummy \\
\hline & Overcome problems with product or process technology & Technology diffusion & Dummy \\
\hline & Encourage the development of new product or services & Encourage markets & Dummy \\
\hline & Establish a new policy organisation or structure & Structure & Dummy \\
\hline & Improve quality of services to firms & Service improvement & Dummy \\
\hline & Transfer of technological skills to firms & Skill Transfer & Dummy \\
\hline & Number of objectives addressed by the programme & NObjectives & Count \\
\hline \multirow{2}{*}{$\begin{array}{l}\text { Evaluation } \\
\text { procedures }\end{array}$} & $\begin{array}{l}\text { Form of Evaluation (No evaluation; official numbers; } \\
\text { sample evaluation; review under the programme) }\end{array}$ & Evaluation & $\begin{array}{l}\text { Categorical } \\
\text { (4 classes) }\end{array}$ \\
\hline & $\begin{array}{l}\text { Efficiency Indicators (\% of participation or use of the } \\
\text { scheme, \% firms that did what expected after having } \\
\text { used the support; \% performing firms after having } \\
\text { benefited from the support) }\end{array}$ & Efficiency Indicators & $\begin{array}{l}\text { Categorical } \\
\text { (3 classes) }\end{array}$ \\
\hline
\end{tabular}


Table 2: Organisational dimensions of policy programmes: Component Loadings matrix

\begin{tabular}{|c|c|c|c|c|c|c|c|c|}
\hline & Dimension & $\begin{array}{c}\text { Horizontal } \\
\text { Local }\end{array}$ & $\begin{array}{l}\text { General } \\
\text { Support }\end{array}$ & Central & $\begin{array}{c}\text { Policy } \\
\text { Capacity }\end{array}$ & $\begin{array}{c}\text { Market } \\
\text { encour- } \\
\text { agement }\end{array}$ & $\begin{array}{l}\text { Knowledge } \\
\text { development }\end{array}$ & $\begin{array}{c}\text { Service } \\
\text { Improve- } \\
\text { ment }\end{array}$ \\
\hline \multirow{5}{*}{$\begin{array}{l}\text { Actors } \\
\text { Addressed }\end{array}$} & Intermediate org & $-0.693^{\mathrm{a}}$ & 0.059 & -0.485 & 0.190 & -0.215 & 0.205 & -0.169 \\
\hline & Not direct benefit & $-0.724^{a}$ & 0.042 & -0.418 & 0.137 & -0.197 & 0.254 & -0.107 \\
\hline & Restrictions to access & $-0.731^{a}$ & 0.086 & -0.410 & 0.117 & -0.159 & 0.122 & 0.049 \\
\hline & Eligible population & $0.599^{a}$ & 0.362 & 0.276 & 0.001 & 0.109 & -0.145 & -0.088 \\
\hline & Forms of access & $0.581^{\mathrm{a}}$ & 0.493 & 0.267 & $0.310^{\mathrm{a}}$ & 0.076 & -0.188 & 0.047 \\
\hline \multirow{5}{*}{$\begin{array}{l}\text { Type of } \\
\text { support }\end{array}$} & Subsidies & 0.236 & $-0.668^{a}$ & $0.448^{\mathrm{a}}$ & -0.200 & -0.067 & 0.058 & 0.061 \\
\hline & Information & $0.411^{\mathrm{a}}$ & $0.584^{\mathrm{a}}$ & -0.188 & 0.093 & 0.261 & -0.200 & -0.158 \\
\hline & Services & $0.590^{\mathrm{a}}$ & -0.186 & -0.347 & -0.077 & -0.138 & 0.038 & -0.071 \\
\hline & Demonstration & 0.376 & $0.637^{\mathrm{a}}$ & -0.046 & 0.013 & 0.301 & 0.073 & 0.068 \\
\hline & Codes & 0.282 & $0.757^{\mathrm{a}}$ & -0.024 & -0.047 & 0.101 & 0.080 & 0.056 \\
\hline \multirow{4}{*}{$\begin{array}{l}\text { Activities } \\
\text { supported } \\
\text { by the } \\
\text { scheme }\end{array}$} & Research & 0.099 & $-0.445^{a}$ & 0.112 & -0.116 & $0.372^{a}$ & $0.360^{\mathrm{a}}$ & -0.064 \\
\hline & Org. management & $0.571^{\mathrm{a}}$ & 0.304 & -0.020 & -0.115 & 0.173 & -0.208 & -0.130 \\
\hline & Technology & 0.330 & $-0.471^{a}$ & -0.069 & -0.096 & $0.336^{\mathrm{a}}$ & 0.209 & -0.036 \\
\hline & Collaboration & 0.034 & $-0.564^{a}$ & 0.099 & 0.026 & $0.432^{\mathrm{a}}$ & 0.138 & 0.044 \\
\hline \multirow{3}{*}{$\begin{array}{l}\text { Customis- } \\
\text { ation }\end{array}$} & Similar country & -0.237 & 0.087 & $0.675^{a}$ & -0.193 & -0.114 & 0.292 & 0.040 \\
\hline & Local orientation & $0.542^{a}$ & -0.215 & $-0.541^{a}$ & -0.102 & -0.148 & -0.208 & -0.042 \\
\hline & Customisation & $0.537^{\mathrm{a}}$ & $-0.617^{a}$ & -0.206 & 0.087 & 0.134 & 0.030 & -0.018 \\
\hline \multirow{9}{*}{$\begin{array}{l}\text { Form of } \\
\text { Implement- } \\
\text { ation }\end{array}$} & Central Management & -0.354 & 0.180 & $0.575^{\mathrm{a}}$ & $0.418^{\mathrm{a}}$ & 0.244 & -0.064 & 0.042 \\
\hline & Other org design & -0.109 & 0.236 & $-0.442^{a}$ & -0.320 & 0.28 & $0.255^{\mathrm{a}}$ & 0.041 \\
\hline & Calls & -0.046 & -0.407 & -0.256 & 0.344 & $0.454^{a}$ & -0.095 & $0.279^{\mathrm{a}}$ \\
\hline & Central implementation & -0.348 & -0.386 & 0.199 & $0.393^{\mathrm{a}}$ & $0.324^{\mathrm{a}}$ & $-0.315^{a}$ & -0.026 \\
\hline & With experts & -0.266 & $0.581^{a}$ & -0.037 & -0.274 & 0.114 & $0.524^{\mathrm{a}}$ & 0.017 \\
\hline & With local actors & -0.246 & -0.199 & -0.163 & $0.537^{\mathrm{a}}$ & 0.014 & $-0.266^{\mathrm{a}}$ & 0.080 \\
\hline & Network local org & $0.598^{\mathrm{a}}$ & -0.228 & $-0.445^{a}$ & -0.324 & -0.129 & -0.110 & -0.020 \\
\hline & Decentralisation & $0.616^{\mathrm{a}}$ & -0.286 & $-0.425^{a}$ & -0.282 & -0.192 & -0.110 & 0.016 \\
\hline & Requirement standards & 0.014 & 0.006 & -0.439 & 0.116 & -0.142 & -0.013 & $0.582^{\mathrm{a}}$ \\
\hline \multirow{4}{*}{$\begin{array}{l}\text { Forms and } \\
\text { responsib- } \\
\text { ilities for } \\
\text { Delivery }\end{array}$} & Delivery & $0.598^{\mathrm{a}}$ & 0.291 & -0.057 & $0.417^{\mathrm{a}}$ & -0.225 & 0.121 & -0.097 \\
\hline & Private org & $0.639^{\mathrm{a}}$ & -0.064 & -0.350 & 0.004 & -0.223 & 0.110 & 0.109 \\
\hline & Public org & 0.380 & 0.162 & -0.168 & $0.532^{a}$ & -0.111 & $0.470^{\mathrm{a}}$ & -0.023 \\
\hline & Different Types org & 0.344 & $0.465^{\mathrm{a}}$ & -0.110 & $0.500^{\mathrm{a}}$ & -0.108 & $0.362^{\mathrm{a}}$ & 0.051 \\
\hline \multirow{4}{*}{$\begin{array}{l}\text { Procure- } \\
\text { ment }\end{array}$} & Delivery Knowledge & -0.268 & -0.009 & -0.33 & -0.038 & 0.224 & 0.073 & $0.677^{\mathrm{a}}$ \\
\hline & Managing knowledge & -0.281 & $0.537^{\mathrm{a}}$ & 0.083 & -0.243 & 0.325 & $0.287^{\mathrm{a}}$ & 0.148 \\
\hline & New org. & -0.456 & 0.032 & -0.385 & $0.250^{\mathrm{a}}$ & -0.123 & 0.173 & -0.449 \\
\hline & New services & -0.155 & -0.026 & -0.380 & $0.211^{\mathrm{a}}$ & $0.455^{\mathrm{a}}$ & -0.256 & -0.230 \\
\hline \multirow{9}{*}{ Objectives } & Consultancy benefits & 0.335 & -0.006 & 0.110 & 0.089 & -0.235 & -0.079 & 0.209 \\
\hline & Awareness & 0.192 & 0.221 & -0.029 & 0.111 & 0.249 & -0.409 & -0.010 \\
\hline & BP diffusion & $0.452^{\mathrm{a}}$ & $0.571^{\mathrm{a}}$ & -0.078 & -0.261 & 0.011 & -0.123 & 0.002 \\
\hline & Technology diffusion & 0.379 & $-0.459^{a}$ & -0.085 & 0.047 & 0.281 & $0.410^{\mathrm{a}}$ & -0.147 \\
\hline & Encourage markets & -0.103 & -0.073 & -0.209 & 0.177 & $0.569^{a}$ & 0.184 & -0.006 \\
\hline & Structure & -0.203 & 0.058 & $-0.542^{a}$ & 0.092 & 0.081 & -0.158 & $-0.491^{a}$ \\
\hline & Service improvement & -0.262 & 0.068 & -0.379 & 0.027 & -0.132 & -0.150 & $0.548^{a}$ \\
\hline & Skill Transfer & $0.510^{\mathrm{a}}$ & -0.305 & 0.080 & -0.261 & -0.058 & $0.405^{\mathrm{a}}$ & -0.066 \\
\hline & NObjectives & 0.444 & 0.225 & -0.352 & -0.079 & 0.483 & 0.129 & 0.060 \\
\hline \multirow{2}{*}{$\begin{array}{l}\text { Evaluation } \\
\text { procedures }\end{array}$} & Evaluation & $0.550^{\mathrm{a}}$ & -0.202 & 0.186 & $0.594^{a}$ & -0.149 & 0.250 & 0.059 \\
\hline & Efficiency Indicators & $0.602^{a}$ & -0.095 & 0.164 & $0.559^{a}$ & -0.146 & 0.207 & 0.095 \\
\hline $\begin{array}{l}\text { Cronbach' } \\
\text { Alpha }\end{array}$ & & 0.846 & 0.802 & 0.728 & 0.674 & 0.660 & 0.616 & 0.653 \\
\hline
\end{tabular}

(') Variables included for computation of the Cronbach's Alpha tests. 
Table 3: Results of the Cluster analyses

\begin{tabular}{||c||c||c||}
\hline \multicolumn{1}{|c|}{$\begin{array}{c}\text { ALL } \\
\text { (7 clusters: } 149 \text { obs.) }\end{array}$} & $\begin{array}{c}\text { France } \\
\text { (6 clusters: } 68 \text { obs.) }\end{array}$ & $\begin{array}{c}\text { UK } \\
\text { (6 clusters: 81 obs.) }\end{array}$ \\
\hline \hline Label creation & Label creation & Label creation \\
\hline Awareness diffusion & Awareness diffusion & Awareness diffusion \\
\hline Central financial subsidies & Market encouragement & Central financial subsidies \\
\cline { 2 - 2 } Policy structure development & Policy structure development \\
\hline Local support framework & Local support framework & Local services structure \\
\hline Local services structure & Local services structure & \\
\hline Flagship & Local Diffusion structures & Flagship \\
\hline
\end{tabular}


Table 4: Types of cluster and main policy design dimensions

\begin{tabular}{|c|c|c|c|c|c|c|c|c|c|c|c|c|}
\hline & \multicolumn{12}{|c|}{ Policy Dimensions } \\
\hline & \multicolumn{4}{|c|}{ Knowledge Dimension } & \multicolumn{4}{|c|}{ Support Dimension } & \multicolumn{4}{|c|}{$\begin{array}{c}\text { Implementation } \\
\text { Dimension }\end{array}$} \\
\hline \multirow{2}{*}{ Cluster Type } & \multicolumn{2}{|c|}{ Horizontal } & \multicolumn{2}{|c|}{ Vertical } & \multicolumn{2}{|c|}{ Specific } & \multicolumn{2}{|c|}{ General } & \multicolumn{2}{|c|}{ Local } & \multicolumn{2}{|c|}{ Central } \\
\hline & France & UK & France & UK & France & UK & France & UK & France & UK & France & UK \\
\hline Label creation & & & $*$ & $*$ & & & $*$ & $*$ & & & * & $*$ \\
\hline $\begin{array}{c}\text { Awareness of } \\
\text { diffusion }\end{array}$ & $*$ & $*$ & & & & & $*$ & $*$ & & & $*$ & $*$ \\
\hline $\begin{array}{c}\text { Central financial } \\
\text { subsidies }\end{array}$ & \multirow{2}{*}{$*_{\mathrm{a}}$} & $*$ & \multirow{2}{*}{$*_{\mathrm{a}}$} & & \multirow{2}{*}{$*_{\mathrm{a}}$} & $*$ & & & & & \multirow{2}{*}{$*_{\mathrm{a}}$} & $*$ \\
\hline $\begin{array}{c}\text { Policy structure } \\
\text { development }\end{array}$ & & & & $*$ & & $*$ & & & & & & $*$ \\
\hline $\begin{array}{l}\text { Local support } \\
\text { framework }\end{array}$ & $*$ & \multirow{2}{*}{$*_{\mathrm{b}}$} & & & \multirow[t]{2}{*}{$*$} & & & \multirow{2}{*}{$*_{\mathrm{b}}$} & $*$ & \multirow{2}{*}{$*_{\mathrm{b}}$} & & \\
\hline $\begin{array}{l}\text { Local service } \\
\text { structure }\end{array}$ & $*$ & & & & & & $*$ & & $*$ & & & \\
\hline Flagship & * & $*$ & & $*$ & & $*$ & & $*$ & $*$ & $*$ & * & $*$ \\
\hline
\end{tabular}

Note 1: Cluster analysis based on 68 observations for France and 81 observations for the UK

Note 2: (a) Market Encouragement; (b) Local Services 
Table 5: Results of Logistic regressions: Country and Period as independent variables

\begin{tabular}{|c|c|c|c|}
\hline & Dependent variable & COUNTRY & YEAR \\
\hline Type of support & $\begin{array}{l}\text { Subsidies } \\
\text { Information } \\
\text { Services } \\
\text { Demonstration } \\
\text { Codes } \\
\end{array}$ & $\begin{array}{l}* \\
* \\
* \\
*\end{array}$ & \\
\hline $\begin{array}{l}\text { Activities supported by } \\
\text { the scheme }\end{array}$ & $\begin{array}{l}\text { Research } \\
\text { Org. management } \\
\text { Technology } \\
\text { Collaboration } \\
\end{array}$ & $\begin{array}{l}* \\
* \\
*\end{array}$ & $*$ \\
\hline Customisation & $\begin{array}{l}\text { Similar country } \\
\text { Local orientation } \\
\text { Customisation } \\
\end{array}$ & $\begin{array}{l}* \\
*\end{array}$ & \\
\hline $\begin{array}{l}\text { Form of programme } \\
\text { Implementation }\end{array}$ & $\begin{array}{l}\text { Central Management } \\
\text { Other org design } \\
\text { Calls } \\
\text { Central Implementation } \\
\text { With experts } \\
\text { With local actors } \\
\text { Network local org } \\
\text { Level Decentralisation } \\
\text { Requirement standards }\end{array}$ & $\begin{array}{l}* \\
* \\
* \\
*\end{array}$ & $\begin{array}{l}* \\
* \\
* \\
*\end{array}$ \\
\hline Procurement & $\begin{array}{l}\text { Delivery Knowledge } \\
\text { Management knowledge } \\
\text { New org. } \\
\text { New services capacity }\end{array}$ & & $\begin{array}{l}* \\
*\end{array}$ \\
\hline $\begin{array}{l}\text { Objectives of } \\
\text { programmes }\end{array}$ & $\begin{array}{l}\text { Consultancy benefits } \\
\text { Awareness } \\
\text { BP diffusion } \\
\text { Technology diffusion } \\
\text { Market encouragement } \\
\text { Structure } \\
\text { Service improvement } \\
\text { Skill Transfer }\end{array}$ & * & $*$ \\
\hline
\end{tabular}

Note 1: * Significance at least $5 \%$

Note 2: 204 observations in the corrected data (France 114, UK 90)

Note 3: Because of the reduced number of observations in some of categories of variables related to "actors addressed', "forms and responsibilities for delivery" and to "evaluation", a good estimation of a multinomial logistic model was not possible. 
Table 6: Summarised results of Logistic regressions on the three Design Dimensions with Period, Country as independent variables

\begin{tabular}{|l||c|c|}
\hline Dependent variable & COUNTRY & YEAR \\
\hline Local & $*$ & \\
Central & $*$ & \\
Horizontal & & \\
Vertical & $*$ & \\
Specific & $*$ & \\
General & & \\
\hline
\end{tabular}

Note $1: *$ significance at least $5 \%$

Note 2: 204 observations (France 114, UK 90) 
Figure 1: Three dimensions to analyse organisation / design of policy programmes

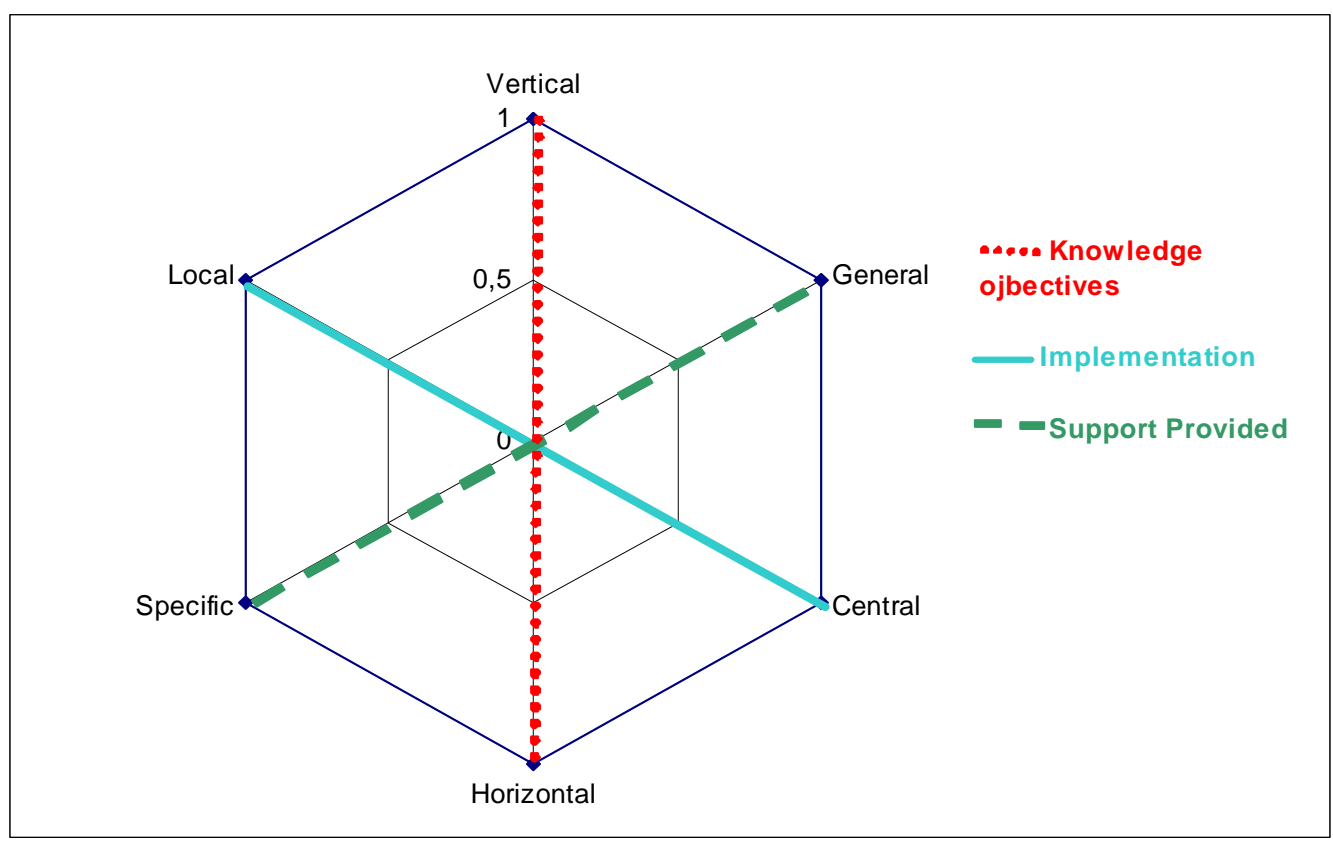

Note: Elaboration by the authors 
Figure 2: Share of each type of policy programme in the national portfolios

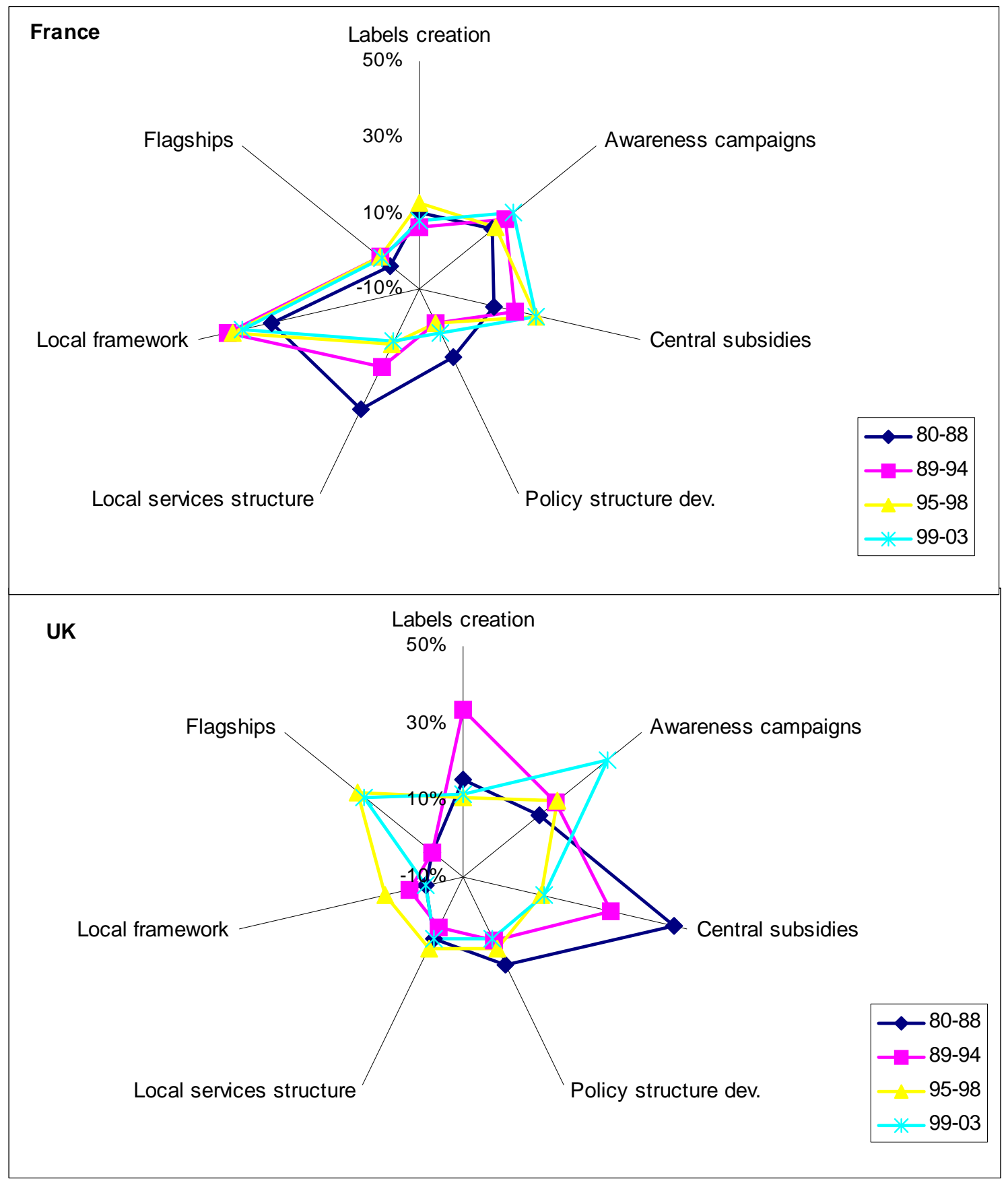

Note: Observations UK: period 1 (13); period 2 (24); period 3 (27); period 4 (26). France: period 1 (21); period 2 (30); period 3 (29); period 4 (34) 
Figure 3: Share of each Design Dimension in the national portfolios of policy activities

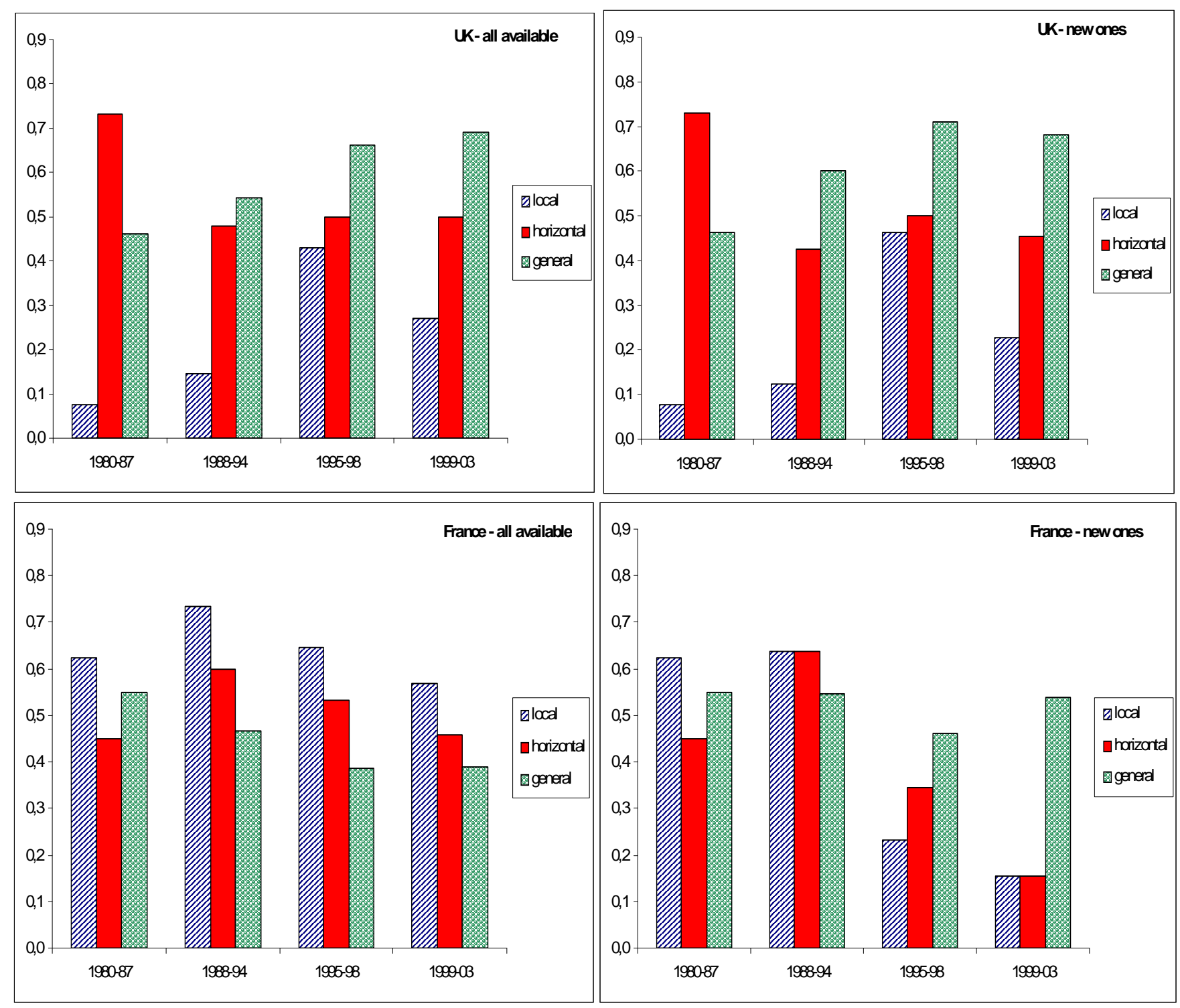

Note 1: programmes functioning UK: period 1 (13); period 2 (24); Period 3 (27); period 4 (26). France: period 1 (21); period 2 (30); period 3 (29); period 4 (34).

Note 2: new programmes UK: period 1 (13); period 2 (20); Period 3 (26); period 4 (22). France: period 1 (21); period 2 (21); period 3 (13); period. 


\section{ANNEX}

Table 1 -British and French innovation programmes grouped into Seven Clusters

\begin{tabular}{|c|c|c|c|c|c|c|c|}
\hline & Label creation (1) & $\begin{array}{c}\text { Central } \\
\text { subsidies (2) }\end{array}$ & $\begin{array}{l}\text { Local Support } \\
\text { Framework (3) }\end{array}$ & $\begin{array}{c}\text { Local } \\
\text { services } \\
\text { structure (4) }\end{array}$ & Flagships (5) & Awareness diffusion (6) & \begin{tabular}{|c|} 
Policy \\
structure \\
development \\
$(7)$ \\
\end{tabular} \\
\hline UK & $\begin{array}{l}\text { Purchasing consultant } \\
\text { NQC associations } \\
\text { Masters } \\
\text { MOPS } \\
\text { Prompt Payment } \\
\text { Benchmarking Challenge } \\
\text { BQF } \\
\text { Effective Business } \\
\text { Campaign } \\
\text { Investors in People } \\
\text { MCI } \\
\text { Brokerage service } \\
\text { DTI's model trade assoc } \\
\text { Standards professional } \\
\text { competence } \\
\text { TMB } \\
\text { NSSF } \\
\text { TrustUK initiative }\end{array}$ & $\begin{array}{l}\text { BAQS } \\
\text { BTAS } \\
\text { Manufactory } \\
\text { Advisory Service } 80 \\
\text { Smart } \\
\text { TCS } \\
\text { CI } \\
\text { EI - DTI RO } \\
\text { Manufacturing } \\
\text { Planning } \\
\text { Implementation } \\
\text { TAL } \\
\text { Tax reliefs } \\
\text { EMIE; employee } \\
\text { ownership } \\
\text { R\&D tax credit } \\
\text { Supply Chain } \\
\text { Groups }\end{array}$ & $\begin{array}{l}\text { Inside UK enterprise } \\
\text { Small firms service } \\
\text { Benchmarking } \\
\text { service } \\
\text { Diagnostic service } \\
\text { Skills SMEs }\end{array}$ & $\begin{array}{l}\text { TEC } \\
\text { Regional } \\
\text { Supply Offices } \\
\text { Regional } \\
\text { Challenge } \\
\text { Sector } \\
\text { Challenge } \\
\text { Innovative } \\
\text { cluster fund }\end{array}$ & $\begin{array}{l}\text { Better pay } \\
\text { practices } \\
\text { Bio means } \\
\text { business } \\
\text { BL services } \\
\text { Design best- } \\
\text { practices } \\
\text { Environmental } \\
\text { best practices } \\
\text { IT for All } \\
\text { IT for Business } \\
\text { BIOWISE } \\
\text { Manufacturing } \\
\text { Advisory } \\
\text { SBS } \\
\text { UK online for } \\
\text { business }\end{array}$ & $\begin{array}{l}\text { National quality Info centre } \\
\text { NQC- promotional } \\
\text { Enterprise Initiative campaign } \\
\text { ISO } 9000 \text { SMEs guide } \\
\text { M90s-2 } \\
\text { MS90s } \\
\text { TickIT DTI } \\
\text { Bench index } \\
\text { BuyIT; enterprise zone } \\
\text { MS90 -3 } \\
\text { People make Profit } \\
\text { Scoreboards } \\
\text { Connect } \\
\text { DTI MBP eBet } \\
\text { Fit for the Future } \\
\text { Great place to work } \\
\text { Learndirect } \\
\text { Living innovation }\end{array}$ & $\begin{array}{l}\text { DTIRO } \\
\text { QA register } \\
\text { BL } \\
\text { ROTT } \\
\text { Local support } \\
\text { centres } \\
\text { RDA } \\
\text { SBS Next Step } \\
\text { Agency } \\
\text { Supernet } \\
\text { RCME } \\
\text { Manufacturing }\end{array}$ \\
\hline
\end{tabular}




\begin{tabular}{|c|c|c|c|c|c|c|c|}
\hline & & & & & & $\begin{array}{l}\text { National Business Debtline } \\
\text { Partnerships with People } \\
\text { C. excellence manag. leadership } \\
\text { UK C. Electronic Business }\end{array}$ & \\
\hline France & $\begin{array}{l}\text { IRDQ } \\
\text { Fonds assurance formation } \\
\text { AFAQ } \\
\text { OPQCM } \\
\text { RTT } \\
\text { Norme formation } \\
\text { Norme Conseils de gestion } \\
\text { (CGAH) } \\
\text { CRITT_CRT } \\
\text { AFNOR-AFAQ } \\
\text { Signature électronique }\end{array}$ & $\begin{array}{l}\text { Credit recherche } \\
\text { CIFRE } \\
\text { Credit normalisation } \\
\text { AQCEN } \\
\text { Societe Information } \\
\text { ARI } \\
\text { UCIP } \\
\text { TechnologiesCles } \\
\text { NTIC Innovation } \\
\text { Services } \\
\text { Partenaires gagner } \\
\text { Performances } \\
\text { Concours creation } \\
\text { entreprises } \\
\text { Fami }\end{array}$ & $\begin{array}{l}\text { FRAC } \\
\text { FACT } \\
\text { DRIRE visits } \\
\text { Aide au projet } \\
\text { d'innovation } \\
\text { FRATT } \\
\text { ARITT } \\
\text { ARC } \\
\text { ATOUT } \\
\text { LOGIC } \\
\text { ACE } \\
\text { ANACT /ARACT } \\
\text { ADEME Aide á } \\
\text { decision } \\
\text { Prestation } \\
\text { technologique reseau } \\
\text { ARTT appui conseils } \\
\text { E-atout }\end{array}$ & $\begin{array}{l}\text { NOREX } \\
\text { RNPQ } \\
\text { CRITT } \\
\text { Chambres } \\
\text { metiers } \\
\text { CCI } \\
\text { Centres Design } \\
\text { RDT }\end{array}$ & $\begin{array}{l}\text { Actions } \\
\text { collectives }\end{array}$ & $\begin{array}{l}\text { AFCERQ } \\
\text { Train de la qualite } \\
\text { Tourfrance1 } \\
\text { ADEME Diffusion } \\
\text { Assises } \\
\text { Prix Qualite } \\
\text { Mois Qualite } \\
\text { TourFrance2 } \\
\text { MFQ } \\
\text { MININFO } \\
\text { IES } \\
\text { Competences entreprise } \\
\text { Guide ISO } \\
\text { Inovation scoreboard } \\
\text { Nouvel referential prix } \\
\text { Technologies organizationelles } \\
\text { Observatoire competences } \\
\text { Standarmedia } \\
\text { Mission ecommerce }\end{array}$ & $\begin{array}{l}\text { Reportoire des } \\
\text { stages } \\
\text { Tertiaire } \\
\text { industriel } \\
\text { Besoins des } \\
\text { entreprises }\end{array}$ \\
\hline
\end{tabular}


Table 2 - The profile of the seven clusters of innovation policy programmes

\begin{tabular}{|c|c|c|c|c|c|c|c|}
\hline & $\begin{array}{l}\text { Labels } \\
\text { creation } \\
\text { (1) }\end{array}$ & $\begin{array}{l}\text { Central } \\
\text { subsidies } \\
\text { (2) }\end{array}$ & $\begin{array}{c}\text { Local } \\
\text { Support } \\
\text { Frame. } \\
(3)\end{array}$ & $\begin{array}{c}\text { Local } \\
\text { Serv. } \\
\text { Struct. } \\
(4)\end{array}$ & $\begin{array}{c}\text { Flagship } \\
\text { s (5) }\end{array}$ & $\begin{array}{c}\text { Awarene } \\
\text { ss Diff. } \\
\text { (6) }\end{array}$ & $\begin{array}{c}\text { Policy } \\
\text { Struct. } \\
\text { Devel.(7) }\end{array}$ \\
\hline Intermediate org & 0.9 & 0.0 & 0.0 & 0.8 & 0.0 & 0.2 & 1.0 \\
\hline Not direct benefit & 1.0 & 0.0 & 0.0 & 0.5 & 0.0 & 0.1 & 1.0 \\
\hline Restrictions to access & 0.5 & 0.3 & 0.3 & 0.3 & 0.2 & 0.1 & 0.5 \\
\hline Eligible population & 0.4 & 0.6 & 0.7 & 0.5 & 0.8 & 0.7 & 0.4 \\
\hline Forms of access & 0.1 & 0.3 & 0.4 & 0.3 & 0.5 & 0.5 & 0.1 \\
\hline Subsidies & 0.1 & 1.0 & 0.8 & 0.0 & 0.0 & 0.0 & 0.0 \\
\hline Information & 0.2 & 0.1 & 0.4 & 0.8 & 1.0 & 1.0 & 0.3 \\
\hline Services & 0.1 & 0.3 & 0.8 & 0.8 & 1.0 & 0.1 & 0.0 \\
\hline Demonstration & 0.0 & 0.0 & 0.2 & 0.0 & 0.9 & 0.7 & 0.1 \\
\hline Codes & 0.4 & 0.1 & 0.3 & 0.3 & 0.8 & 1.0 & 0.0 \\
\hline Research & 0.1 & 0.4 & 0.2 & 0.2 & 0.4 & 0.0 & 0.0 \\
\hline Org. management & 0.3 & 0.7 & 0.8 & 0.8 & 1.0 & 1.0 & 0.1 \\
\hline Technology & 0.2 & 0.7 & 0.7 & 0.6 & 0.8 & 0.2 & 0.1 \\
\hline Collaboration & 0.0 & 0.5 & 0.2 & 0.1 & 0.1 & 0.0 & 0.1 \\
\hline Similar country & 1.0 & 1.0 & 1.0 & 0.2 & 0.5 & 0.9 & 0.9 \\
\hline Local orientation & 0.0 & 0.0 & 0.9 & 0.7 & 0.5 & 0.1 & 0.1 \\
\hline Customisation & 0.0 & 0.8 & 1.1 & 1.7 & 1.7 & 0.1 & 0.3 \\
\hline Central Management & 1.1 & 1.9 & 0.2 & 0.6 & 0.5 & 1.5 & 1.9 \\
\hline Other org design & 1.0 & 0.3 & 0.5 & 1.0 & 1.0 & 0.7 & 0.1 \\
\hline Calls & 0.0 & 0.3 & 0.0 & 0.4 & 0.4 & 0.0 & 0.3 \\
\hline Central implementation & 0.0 & 0.6 & 0.0 & 0.4 & 0.0 & 0.1 & 0.8 \\
\hline With experts & 0.9 & 0.0 & 0.0 & 0.0 & 0.7 & 0.6 & 0.0 \\
\hline With local actors & 0.0 & 0.2 & 0.1 & 0.5 & 0.0 & 0.1 & 0.8 \\
\hline Network local org & 0.0 & 0.1 & 0.9 & 0.4 & 0.7 & 0.2 & 0.0 \\
\hline Decentralisation & 0.3 & 0.2 & 0.7 & 0.4 & 0.6 & 0.4 & 0.2 \\
\hline Requirement standards & 0.3 & 0.0 & 0.2 & 0.3 & 0.5 & 0.0 & 0.3 \\
\hline Delivery & 0.0 & 0.1 & 0.3 & 0.2 & 0.4 & 0.3 & 0.0 \\
\hline Private org & 0.2 & 0.1 & 0.3 & 0.2 & 0.3 & 0.2 & 0.2 \\
\hline Public org & 0.2 & 0.2 & 0.4 & 0.3 & 0.5 & 0.2 & 0.1 \\
\hline Different Types org & 0.1 & 0.0 & 0.2 & 0.1 & 0.3 & 0.2 & 0.1 \\
\hline Delivery Knowledge & 0.4 & 0.2 & 0.0 & 0.1 & 0.3 & 0.1 & 0.4 \\
\hline Managing knowledge & 0.8 & 0.2 & 0.1 & 0.1 & 0.4 & 0.9 & 0.1 \\
\hline New org. & 0.5 & 0.0 & 0.1 & 0.4 & 0.0 & 0.1 & 0.8 \\
\hline New services & 0.2 & 0.3 & 0.0 & 1.0 & 0.4 & 0.4 & 0.8 \\
\hline Consultancy benefits & 0.0 & 0.2 & 0.2 & 0.1 & 0.1 & 0.1 & 0.0 \\
\hline Awareness & 0.0 & 0.0 & 0.1 & 0.2 & 0.2 & 0.2 & 0.1 \\
\hline BP diffusion & 0.3 & 0.2 & 0.7 & 0.4 & 0.8 & 0.9 & 0.1 \\
\hline Technology diffusion & 0.0 & 0.4 & 0.5 & 0.3 & 0.7 & 0.1 & 0.2 \\
\hline Encourage markets & 0.3 & 0.3 & 0.1 & 0.1 & 0.7 & 0.2 & 0.6 \\
\hline Structure & 0.2 & 0.0 & 0.1 & 0.8 & 0.0 & 0.2 & 0.6 \\
\hline Service improvement & 0.3 & 0.0 & 0.1 & 0.3 & 0.2 & 0.1 & 0.5 \\
\hline Skill Transfer & 0.0 & 0.3 & 0.7 & 0.0 & 0.7 & 0.0 & 0.0 \\
\hline Evaluation & 0.0 & 0.4 & 0.3 & 0.2 & 0.3 & 0.1 & 0.1 \\
\hline Efficiency Indicators & 0.0 & 0.3 & 0.4 & 0.2 & 0.4 & 0.2 & 0.1 \\
\hline
\end{tabular}

